\title{
GRASIELE RODRIGUES GOES
}

Elaboração e validação de um Instrumento norteador para a supervisão do agente comunitário de saúde pelo enfermeiro: uma ação participativa e colaborativa 

GRASIELE RODRIGUES DE GOES

Elaboração e validação de um Instrumento norteador para a supervisão do agente comunitário de saúde pelo enfermeiro:

uma ação participativa e colaborativa

\section{Versão Corrigida}

Dissertação apresentado à Faculdade de Odontologia da Universidade de São Paulo Programa de Pós-Graduação Formação Interdisciplinar em Saúde para obtenção do título de Mestre em Ciências.

Orientador: Profa. Dra. Maria Helena Morgani de Almeida

São Paulo 
Autorizo a reprodução e divulgação total ou parcial deste trabalho, por qualquer meio convencional ou eletrônico, para fins de estudo e pesquisa, desde que citada a fonte.

Catalogação-na-Publicação

Serviço de Documentação Odontológica

Faculdade de Odontologia da Universidade de São Paulo

Goes, Grasiele Rodrigues de.

Elaboração e validação de um instrumento norteador para a supervisão do agente comunitário de saúde pelo enfermeiro: uma ação participativa e colaborativa / Grasiele Rodrigues de Goes ; orientador Maria Helena Morgani de Almeida -- São Paulo, 2019.

110 p. : fig., tab. ; $30 \mathrm{~cm}$

Dissertação (Mestrado Profissional) - Programa de Mestrado Profissional Interunidades em Formação Interdisciplinar em Saúde - Faculdade de Odontologia da Universidade de São Paulo.

Versão corrigida

1. Saúde da família. 2. Agentes comunitários de Saúde. 3. Enfermeiros. 4. Supervisão de enfermagem. I. Almeida, Maria Helena Morgani de. II. Título. 
Góes GR. Elaboração e validação de um Instrumento norteador para a supervisão do agente comunitário de saúde pelo enfermeiro: uma ação participativa e colaborativa. Dissertação apresentada à Faculdade de Odontologia da Universidade de São Paulo para obtenção do título de Mestre em Ciências da Saúde.

Aprovado em: $12 / 12 / 2019$

\section{Banca Examinadora}

Prof(a). Dr(a). Celso Zilbovicius

Instituição: FO - USP

Julgamento: Aprovado

$\operatorname{Prof}(\mathrm{a}) . \operatorname{Dr}(\mathrm{a})$. Cleide Lavieri Martins

Instituição: FSP - USP

Julgamento: Aprovado

Prof(a). Dr(a). Márcia Maria Pires Camargo Novelli

Instituição: UNIFESP - Externo

Julgamento: Aprovado 

Aos meus pais, dedico esse trabalho, pela importância sempre conferida à minha educação e formação.

A meu companheiro Gustavo, pelo companheirismo e compreensão da importância dessa conquista. 



\section{AGRADECIMENTOS}

A Profa. Dra. Maria Helena Morgani de Almeida, minha orientadora, pela paciência e dedicação durante essa jornada, me instigando e provocando, proporcionando vislumbrar novos conceitos e horizontes, demonstrando as várias formas de pensar a saúde e praticá-la.

A Unidade de Saúde da Família "Aparecidinha", pela oportunidade de trabalhar com uma equipe tão engajada e especial, que me permitiu desenvolver esse projeto.

Aos enfermeiros da Estratégia Saúde da família do Município de Sorocaba, atores importantes durante esse projeto.

Muito Obrigada! 

"Talvez não tenha conseguido fazer o melhor, mas lutei para que o melhor fosse feito. Não sou o que deveria ser, mas Graças a Deus, não sou o que era antes".

Martin Luther King 



\section{RESUMO}

Góes GR. Elaboração e validação de um Instrumento norteador para a supervisão do agente comunitário de saúde pelo enfermeiro: uma ação participativa e colaborativa [dissertação]. São Paulo: Universidade de São Paulo, Faculdade de Odontologia; 2019 Versão Corrigida

Tendo como propósito a qualificação do trabalho do agente comunitário de saúde, e compreendendo a supervisão do enfermeiro como fundamental para o alcance dessa finalidade, o presente estudo tem como objetivo elaborar e validar conteúdo de um instrumento norteador para a supervisão do agente comunitário de saúde pelo enfermeiro na lógica participativa e colaborativa. Trata-se de uma pesquisa qualitativa, exploratória e descritiva realizada em duas fases. A primeira de elaboração do instrumento, a partir de levantamento bibliográfico. A segunda de validação de conteúdo do instrumento por um comitê de especialistas $(n=15)$, por meio da aplicação da técnica Delphi. A técnica foi aplicada em 2 etapas: 1a interrogatório, obtenção de respostas dos especialistas em relação a versão preliminar e elaboração da $1^{\underline{a}}$ versão ajustada; 2 ${ }^{\mathrm{a}}$ interrogatório, obtenção de respostas e elaboração da versão consensuada do instrumento. Os especialistas na $1^{\text {a }}$ etapa opinaram sobre a forma e o conteúdo do instrumento, nessa etapa a média de aprovação do Instrumento foi de $96,85 \%$, na $2^{\underline{a}}$ etapa os especialistas opinaram sobre a $1^{\text {a }}$ versão ajustada do instrumento quanto a conteúdo e linguagem, a aprovação do conteúdo foi de $97,33 \%$ e quanto a linguagem foi de $98,66 \%$. A elaboração e validação do ISACS gerou um produto que busca superar a tradicional visão sobre a supervisão e conceitos, que apoiados em raízes históricas, a concebiam como instrumento de poder e expressão de autoridade, dando lugar à supervisão compartilhada e consciente, onde juntos, enfermeiros e agentes comunitários de saúde, constroem o conhecimento, partilham dúvidas e buscam resoluções de problemas.

Palavras-chave: Saúde da Família. Agente Comunitário de Saúde. Enfermeiro. Supervisão. Instrumento. 



\begin{abstract}
ABSCRACT
Góes GR. Elaboration and validation of a guiding instrument for the supervision of community health agents by nurses: a participatory and collaborative action. [dissertation]. São Paulo: Universidade de São Paulo, Faculdade de Odontologia; 2019 Versão Corrigida

With the purpose of qualifying the work of the community health agent, and understanding the supervision of nurses as fundamental to the achievement of this purpose, this study aims to elaborate and validate the content of a guiding instrument for the supervision of the community health agent by the nurse in the participative and collaborative logic. It is a qualitative, exploratory and descriptive research conducted in two phases. The first elaboration of the instrument, based on bibliographic survey. The second was the content validation of the instrument by a committee of experts $(n=15)$ by applying the Delphi technique. The technique was applied in 2 steps: 1st interrogation, obtaining answers from the experts regarding the preliminary version and elaboration of the 1st adjusted version; 2nd interrogation, obtaining answers and elaboration of the consensual version of the instrument. The specialists in the first stage gave their opinion on the form and content of the instrument, at this stage the average approval of the instrument was $96.85 \%$, In the 2nd stage, the experts gave their opinion on the 1st adjusted version of the instrument regarding content and language, content approval was $97.33 \%$ and language was $98.66 \%$. The elaboration and validation of ISACS has generated a product that seeks to surpass the traditional view on supervision and concepts, which are supported by historical roots, conceived it as an instrument of power and expression of authority, giving way to shared and conscious supervision, where together nurses and community health agents, build knowledge, share doubts and seek problem solving.
\end{abstract}

Keywords: Family Health. Community Health Agent. Nurse. Supervision. Instrument. 



\section{LISTA DE ILUSTRAÇÕES}

Quadro 1.1 - Teorias administrativas e a Supervisão

Figura 3.1 - Unidades de Saúde, Regionais de Saúde e Território de Abrangência

Figura 3.2 - Representação da elaboração do instrumento pela técnica Delphi .....43

Quadro 4.2 - Mapeamento dos artigos em relação ao título do periódico, autores, ano de publicação e idioma. São Paulo,2 018

Quadro 4.3 - Contribuições da revisão bibliográfica para a elaboração da versão preliminar do instrumento. São Paulo, 2018

Quadro 4.4 - Caracterização profissional dos especialistas do Estudo Delphi. São Paulo, 2018

Quadro 4.5 - Sugestões dos especialistas quanto à versão preliminar do ISACS ....59

Quadro 4.6 - Críticas dos especialistas quanto a versão preliminar do ISACS 60

Quadro 4.7 - Comentários dos Especialistas quanto à $1^{\text {a }}$ versão ajustada do ISACS 



\section{LISTA DE TABELAS}

Tabela 4.1 - Pré-teste - versão preliminar 53

Tabela 4.2 - Primeira fase do estudo Delphi, julgamento especialistas - versão preliminar ISACS.

Tabela 4.3 - Julgamento dos Especialistas sobre a $1^{\text {a }}$ versão Ajustada do 



\section{LISTA DE ABREVIATURAS E SIGLAS}

ACS Agente Comunitário de Saúde

APS Atenção Primária à Saúde

DeCS Descritores em Ciências da Saúde

ESF Estratégia Saúde da Família

IBGE Instituto Brasileiro de Geografia Estatística

ISACS Instrumento de Supervisão do Agente Comunitário de Saúde

PACS Programa de Agentes Comunitário de Saúde

PSF Programa Saúde da Família

SIAB Sistema de Informação da Atenção Básica

SUS Sistema único de Saúde

UBS Atenção Primária à Saúde 

SUMARIO

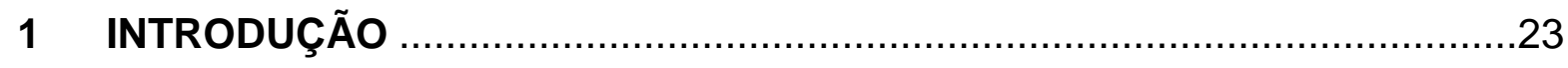

2 OBJETIVO

3 MÉTODO

4 RESULTADO

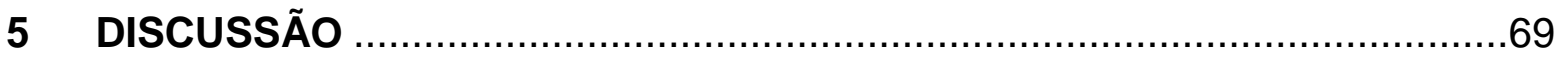

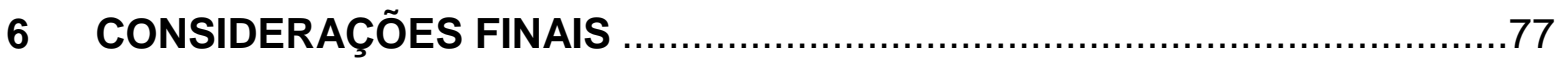

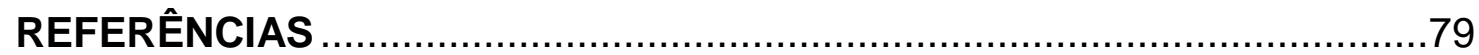

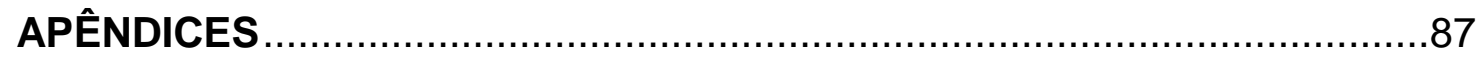

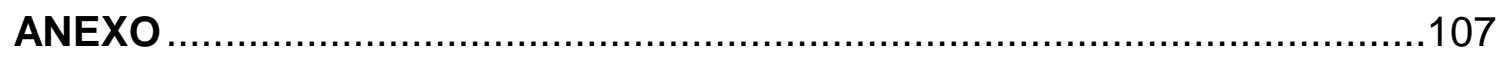





\section{INTRODUÇÃO}

Em minha trajetória profissional, vivenciei o papel de enfermeira em várias instituições de serviços de saúde. Na Estratégia Saúde da Família (ESF) em minha atuação junto a agente comunitário de saúde (ACS), encontrei alguns obstáculos que, por vezes, não sabia como transpor.

Ainda, em momentos pontuais com outros enfermeiros que atuam na ESF, discutindo as nossas atividades e, entre elas, as de supervisão do trabalho do ACS, constatamos que muitas vezes a nossa atuação estava restrita a orientações e busca de soluções para problemas pontuais e, verificação do preenchimento de formulários. Foi então que senti a necessidade de buscar conhecimento sobre o trabalho do enfermeiro com ACS, tendo a supervisão como eixo norteador.

A supervisão sempre foi uma atividade inerente ao exercício profissional dos enfermeiros, devido às peculiaridades da composição da força de trabalho em saúde e em enfermagem, na qual o enfermeiro é o responsável técnico pelas ações de toda equipe de enfermagem.

A Política Nacional de Atenção Básica ${ }^{(1)}$ coloca como atribuição específica do enfermeiro nas equipes de saúde da família, supervisionar as ações do técnico/auxiliar de enfermagem e ACS.

Para desempenhar tal função, o enfermeiro tradicionalmente orienta-se pela visão de supervisão voltada exclusivamente ao gerenciamento e pratica uma gestão vertical, centralizadora, de cunho controlador e punitivo, o que pode decorrer da falta de formação específica para desenvolvimento dessa função. A supervisão no sentido da gestão colaborativa é recente e vem sendo discutida ainda de forma incipiente na área de saúde, havendo pouca literatura sobre o assunto. Essas diferentes formas de supervisionar provavelmente têm desencadeado diferentes formas de atuação do enfermeiro junto o ACS.

Considerando a supervisão do enfermeiro como estratégica para a qualificação do trabalho do ACS na ESF, propõe-se um estudo metodológico voltado à elaboração e validação de um instrumento para planejamento, orientação e acompanhamento do trabalho do Agente Comunitário de Saúde 
pelo Enfermeiro, baseado em uma prática administrativa aberta, flexível, participativa e inovadora.

\subsection{TEORIAS ADMINISTRATIVAS E A SUPERVISÃO}

A segunda fase da revolução industrial (1860-1914) inaugurou uma nova lógica de produção, e suscitou uma profusão de teorias administrativas (Quadro 1.1), com o intuito de aumentar a produção suprindo assim as demandas do mercado capitalista em ascensão.

Nesse contexto Taylor em 1903 elabora a Teoria da Administração Científica. Por meio da aplicação de métodos da ciência positivista, racional e metódica aos problemas administrativos, a teoria objetiva alcançar a máxima produtividade em menor tempo com redução dos desperdícios ${ }^{(2)}$.

Henry Ford em 1908 baseia-se no pensamento de Taylor para criar a Teoria de Linha de Montagem, aplicando-a a fabricação de automóveis. Esta teoria envolve mecanização, linhas de montagens e crescente divisão do trabalho com objetivo de buscar uma produção mais barata e acessível às várias classes sociais da época ${ }^{(3)}$.

Há algum tempo, vem se discutindo, os efeitos negativos da organização do trabalho Taylorista/Fordista sobre os trabalhadores, principalmente no que diz respeito à fragmentação do trabalho e sua divisão entre concepção e execução. Esses aspectos somados ao controle gerencial do processo e à hierarquia rígida têm gerado desmotivação e alienação de trabalhadores, bem como a instabilidade nas cargas de trabalho ${ }^{(4)}$.

Seguidamente, outras teorias administrativas surgiram, entre elas, a Teoria Clássica de Fayol em 1916 que substitui a abordagem analítica e concreta proposta por Taylor por uma abordagem sintética, global e universal, ou seja, enquanto Taylor se preocupava com as tarefas executadas pelos operários, Fayol estava preocupado com os níveis mais altos da hierarquia de uma empresa. Ele considerava que a gestão e o controle eram a chave para o sucesso da organização, estabelecendo princípios gerais da administração e 
as funções do administrador, quais sejam organizar, planejar, coordenar, comandar e controlar ${ }^{(2,5)}$.

Servo ${ }^{(6)}$, em 1999, critica a generalidade e a racionalidade proposta pelas Teorias da Administração, em função de não considerarem o elemento humano e levarem o trabalhador a executar uma função totalmente engessada, se assemelhando a uma máquina, onde seus desejos, seus valores e propósitos não são considerados.

Com forma de assegurar a produtividade, o cumprimento de ordens e regulamentos, surge à necessidade de supervisionar o trabalho e o trabalhador, destacando falhas e aplicando sanções. ${ }^{(7,8)}$. Essa supervisão, pautada pela relação assimétrica entre supervisor e supervisionado, com base na autoridade, imposição e fiscalização caracteriza um modelo verticalizado e hierarquizado. ${ }^{(9)}$.

Em oposição à administração clássica e ao modelo burocrático, surge o Movimento das Relações Humanas em 1932 que embora não confronte o Taylorismo, combate o formalismo na administração e muda seu foco para os grupos informais e suas inter-relações. Esse movimento deposita na motivação a expectativa de levar o indivíduo a trabalhar para atingir os objetivos da organização, defende a participação do trabalhador na tomada de decisões, porém com restrições referentes ao padrão de liderança $\operatorname{adotado}^{(3)}$.

A partir do Movimento das Relações Humanas, começaram a surgir mudanças na forma de supervisionar, associando controle e educação, propondo uma relação de parceria e uma gestão colaborativa ${ }^{(9)}$. Depreende-se que o conceito e a prática de supervisão podem apropriar-se de diferentes sentidos com base nos princípios e valores a serem empregados ${ }^{(8)}$.

Como exemplifica Moreira ${ }^{(10)}$

Quando falamos em supervisão, de que visão de formação e de que pedagogia estamos a falar? (...) A supervisão pode ser exercida no sentido de manter o status quo, reforçar injustiças e impedir a mudança, mas pode também ter uma orientação transformadora e emancipatória, potencialmente transgressora e subversiva, assente nos valores da liberdade e da responsabilidade social. (Moreira, 2011, p. 12).

Assim, apesar de despontarem reações contrárias à administração clássica e ao modelo burocrático esses ainda exercem forte influência na organização do trabalho e no gerenciamento do setor saúde. 
Conforme descrito por Matos ${ }^{(4)}$ a estrutura organizacional dos hospitais, por exemplo, ainda hoje pauta-se na lógica da autoridade legal, herdada da concepção burocrática. As relações são hierarquizadas, verticais, com excessiva formalização e fragmentações das responsabilidades nessa perspectiva correspondem à administração clássica. Considera-se que essa lógica, ainda predominante na Saúde, gera resultados que não mais respondem as atuais e complexas necessidades do setor.

\subsection{A SUPERVISÃO NA SAÚDE E NA ENFERMAGEM}

A supervisão, tradicionalmente considerada como um instrumento de gestão em serviços de saúde foi incorporada no Brasil, a partir da década de 70, principalmente em unidades hospitalares, devido ao seu grau de importância para o aumento da produtividade. No entanto, sua maior aplicação ocorreu nos serviços de saúde da rede pública ${ }^{(11)}$.

$\mathrm{Na} 2^{\mathrm{a}}$ metade do século XIX, o modelo proposto por Florence Nightingale para a área de enfermagem, motivado pela lógica capitalista de sistematização do trabalho, estabeleceu a divisão entre trabalho intelectual e manual e a hierarquização no trabalho da enfermagem, ainda tão presente em nossa realidade. Neste modelo a enfermeira desempenha o papel de gerente centralizadora do saber, que controla 0 processo de trabalho de enfermagem e delega atividades fragmentadas aos demais trabalhadores da área ${ }^{(4,12)}$.

Ainda como herança desse modelo pode se destacar: a ênfase no "como fazer", a divisão do trabalho em tarefas, a excessiva preocupação com manuais de procedimentos, rotinas, normas, escalas, fragmentação da assistência, dentre outros. O poder de decisão é centralizado na enfermeira, a preocupação é voltada para o cumprimento de tarefa e o desempenho é avaliado pelo quantitativo de procedimentos realizados ${ }^{(4)}$. Evidencia-se que essa forma de trabalho tem contribuído para um distanciamento entre os integrantes das equipes ${ }^{(7)}$. 
Assim, apesar das contribuições que o modelo clássico de administração trouxe para a organização do trabalho, essa concepção não se adéqua mais, já que produz efeitos negativos que prejudicam a agilidade e a operacionalização do processo de trabalho ${ }^{(13)}$.

A despeito dessas constatações muitas instituições de ensino, em especial na área de enfermagem, continuam seguindo a linha voltada às teorias administrativas tradicionais, não preparando o enfermeiro para uma gerência inovadora $^{(4)}$.

Santiago e Cunha ${ }^{(14)}$ consideram que a falta de conhecimento dos profissionais e a deficiência no preparo das instituições acarreta em uma supervisão insatisfatória e superficial.

Entretanto, salienta-se que processo de supervisão em enfermagem tem recebido novos olhares, na qual essa passa a ser vista na perspectiva da convisão que significa gestão "colaborativa" ou construção conjunta, o que traz inúmeras possibilidades: de crescimento profissional através do estabelecimento de vínculos afetivos (e efetivos); de reflexão sobre as práticas e de questionamento dos modelos de atenção à saúde ${ }^{(9)}$.

Nesse sentido, a supervisão é entendida como um trabalho conjunto da equipe de supervisão e da equipe de Saúde, em que a primeira tem o papel de facilitar que as próprias equipes analisem suas práticas e reflitam sobre o trabalho e os resultados alcançados. A supervisão assim concebida é referenciada como evento e processo inerente ao trabalho coletivo realizado por profissionais especializados que prestam suporte ou apoio gerencial e técnico e que, quando bem encaminhada, determina melhor desempenho da equipe e qualidade do serviço prestado $^{(15)}$.

Vale destacar que dispomos atualmente de novos conhecimentos e habilidades voltados a uma prática administrativa mais aberta, flexível e participativa com potencial para responder a complexidade da demanda em saúde e a busca por novas formas de gestão dos serviços. Ressalta-se que nessa a supervisão configurasse como instrumento de construção de liberdade e autonomia ${ }^{(16)}$. 
Quadro 1.1 - Teorias administrativas e a Supervisão

\begin{tabular}{|c|c|c|}
\hline $\begin{array}{c}\text { Teorias } \\
\text { Administrativas }\end{array}$ & Características/Princípios & Supervisão \\
\hline $\begin{array}{c}\text { Teoria da } \\
\text { Administração } \\
\text { Científica } \\
\text { Taylor (USA) } 1903\end{array}$ & $\begin{array}{l}\text { Aumentar a produtividade. } \\
\text { Divisão de trabalho. } \\
\text { Ênfase nas Tarefas }\end{array}$ & $\begin{array}{l}\text { Supervisão Funcional. } \\
\text { Controle sobre o } \\
\underline{\text { trabalho }}\end{array}$ \\
\hline $\begin{array}{l}\text { Teoria Clássica da } \\
\text { Organização } \\
\text { Fayol (França) } 1916\end{array}$ & $\begin{array}{c}\text { Aumentar eficiência da } \\
\text { organização (prever, } \\
\text { organizar, comandar, } \\
\text { controlar). } \\
\text { Ênfase na Estrutura }\end{array}$ & $\begin{array}{l}\text { Instrumento de gerencia. } \\
\text { Relacão vertical } \\
\text { Chefe/Supervisionado. } \\
\text { Fazer a maquina funcionar }\end{array}$ \\
\hline $\begin{array}{l}\text { Relações Humanas- } \\
\text { Psicologia e } \\
\text { Sociologia do } \\
\text { Trabalho } \\
\text { (oposição à teoria } \\
\text { clássica) } 1932\end{array}$ & $\begin{array}{l}\text { Elementos emocionais, } \\
\text { Motivação, liderança, } \\
\frac{\text { valorizacão do }}{\text { trabalhador }} \\
\text { (humanização) }\end{array}$ & $\begin{array}{c}\text { Mecanismo de } \\
\text { comunicação e } \\
\text { encorajamento. } \\
\text { Cooperação do } \\
\text { trabalhador. Supervisor é } \\
\text { líder formal para garantir } \\
\frac{\text { o desenvolvimento do }}{\text { trabalho }}\end{array}$ \\
\hline $\begin{array}{c}\text { Atual } \\
\text { Estruturas } \\
\text { organizacionais } \\
\text { mais flexíveis, } \\
\text { adaptáveis e } \\
\text { ajustáveis a } \\
\text { mutações rápidas. }\end{array}$ & $\begin{array}{c}\text { Maior eficiência no alcance } \\
\text { de resultados, Objetivo } \\
\text { organizacionais } \\
\underline{\text { conciliados aos }} \\
\text { individuais. }\end{array}$ & $\begin{array}{c}\begin{array}{c}\text { Supervisão } \\
\text { descentralizada, }\end{array} \\
\frac{\text { participativa. }}{\underline{\text { Cogestão }}}\end{array}$ \\
\hline
\end{tabular}

Fonte: Reis CCL, et al. Supervisão no programa de saúde da família: limites e possibilidades [tese] [internet]; Rio de Janeiro 2001. [citado 12 set 2017]. Disponível em: http://teses.icict.fiocruz.br/pdf/reiscclm.pdf.

\subsection{ESTRATÉGIA SAÚDE DA FAMÍLIA E A SUPERVISÃO}

Após a Conferência internacional de Cuidados Primários de Saúde em 1978, foi elaborada a declaração de Alma-Ata, que expressava a necessidade de uma ação - por parte dos governos e de todos aqueles que trabalham com saúde - 
voltada a atenção primária e que enfatizasse tecnologias ditas simplificadas e de baixo custo para utilização nesse âmbito da atenção em saúde. Esse modelo da atenção primária se contrapunha ao modelo hospitalocêntrico, alimentando assim uma crítica político-ideológica com uma proposta de reformulação da politicas públicas e de reorganização do sistema de saúde ${ }^{(17)}$.

A declaração de Alma-Ata abriu caminhos para outras importantes conferências e debates, para o aprimoramento da discussão sobre atenção primária, direito a saúde, equidade e universalidade. E em agosto de 1986, ocorreu a $8^{\mathrm{a}}$ Conferência Nacional de Saúde, que foi um dos principais momentos da luta pela universalização da saúde no Brasil, e contou com a participação de diferentes atores sociais implicados na transformação dos serviços de saúde. Essa Conferência deixou como seu principal legado a elaboração de um projeto Sanitário que defendia a criação de um Sistema Único de Saúde (SUS) ${ }^{(18)}$.

A organização da saúde no país passou por intensas mudanças com a regulamentação do SUS, através das Leis Federais 8.080/90, que dispõe sobre as condições para a promoção, proteção e recuperação da saúde, a organização e o funcionamento dos serviços correspondentes e com a Lei 8.142/90, que dispõe sobre a participação da comunidade na gestão do SUS e sobre as transferências intergovernamentais de recursos financeiros para a área da saúde ${ }^{(19,20)}$.

Como parte desse processo de mudança que ocorria a partir do desenvolvimento do SUS, o Ministério da Saúde formulou em 1991 o Programa de Agentes Comunitários de Saúde (PACS) com a finalidade de contribuir para a redução das mortalidades infantil e materna, principalmente nas regiões Norte e Nordeste, através da extensão de cobertura dos serviços de saúde para as áreas mais pobres.

A partir da experiência acumulada com o PACS,o Ministério da Saúde compreendeu a importância do serviço prestado pelo Agente Comunitário, deixou de enfocar no indivíduo e passou a entender a família como unidade de ação programática de saúde introduzindo a noção de cobertura por família ${ }^{(21)}$.

Assim o Ministério da Saúde em 1994 implantou o Programa de Saúde da Família (PSF), como uma estratégia de reorientação do modelo assistencial a partir da atenção básica assumindo compromisso de prestar assistência universal, integral, equânime, contínua e resolutiva, seja na Unidade de saúde ou no domicilio. 
O programa propõe ainda a humanização das práticas de saúde, tendo em vista o vinculo do profissional com a comunidade ${ }^{(22)}$.

Cabe ressaltar, que esse movimento de "olhar a família" já havia sido experienciado em outros países como Canadá, Cuba, Suécia e Inglaterra, que desenvolveram modelos de assistência voltada à família que serviram de referência para a estruturação do programa Brasileiro ${ }^{(21)}$.

Embora rotulado como programa, o PSF, por suas especificidades, foge à concepção usual dos demais programas concebidos pelo Ministério da Saúde, por não se tratar de uma intervenção vertical e paralela às atividades dos serviços de saúde. Ao contrário, caracteriza-se como estratégia que possibilita a integração e o compartilhamento entre o serviço de saúde e a população. Assim em 2006 o PSF deixou de ser programa e passou a ser uma estratégia permanente na atenção básica em saúde, desse modo passou a ser denominado de Estratégia Saúde da Família - ESF ${ }^{(21,23)}$.

A ESF é composta por equipe multiprofissional que possui, no mínimo, médico generalista ou especialista em saúde da família ou médico de família e comunidade, enfermeiro generalista ou especialista em saúde da família, auxiliar ou técnico de enfermagem e agentes comunitários de saúde (ACS). Pode-se acrescentar a esta composição, como parte da equipe multiprofissional, os profissionais de saúde bucal ${ }^{(24)}$.

Essa equipe deve ser capaz de compreender o sujeito, a família e a comunidade com uma visão integral. Para isso, deve estar qualificada a desenvolver suas práticas de maneira eficaz, resolutiva e humanizada, com o propósito que suas ações respondam as necessidades da comunidade.

É papel do enfermeiro segundo Portaria no 2.488, de 21 de outubro de $2011^{(25)}$, contribuir e realizar atividades de educação permanente da equipe de enfermagem e de outros membros da equipe, bem como supervisionar planejar, gerenciar e avaliar as ações desenvolvidas pelos ACS.

O documento do Ministério da Saúde ${ }^{(26)}$, destaca que a intenção da supervisão é elevar a qualidade do serviço prestado, contribuindo assim para melhora da saúde do indivíduo, da família e a comunidade.

Há muito tempo se discute no Ministério da Saúde, a diferenciação entre supervisão tradicional e supervisão moderna, onde a tradicional se caracteriza pela forma fiscalizadora, limitando-se a apontar erros e aplicar sanções. Essa 
modalidade de supervisão ocorre de forma esporádica, impositiva e autoritária onde o supervisor tem papel de destaque e atua sozinho. Já a supervisão moderna associa acompanhamento e educação, atua junto ao supervisionado, diagnosticando e buscando a solução de problemas, ocorre de forma sistemática e planejada, é exercida em equipe, com característica de cooperação, se adapta as diferenças individuais, contribuindo para o desenvolvimento pessoal e profissional ${ }^{(26)}$.

Refletindo sobre as expectativas em torno das ações desenvolvidas pela ESF, que sejam abrangentes e resolutivas em relação a maior parte dos problemas que afetam o indivíduo, a família e a comunidade considera-se que supervisão do ACS pelo enfermeiro deva permitir aos envolvidos superarem o aparente desinteresse e se envolverem com o processo de trabalho, através de uma supervisão compartilhada, que privilegia o diálogo e a integração.

Propõe-se desse modo supervisão que supere a assimetria de conhecimento entre as partes - supervisor e supervisionado - e possibilite a relação de ensinoaprendizagem que se estabelece entre ambas ${ }^{(16)}$.

Paulo Freire ${ }^{(27)}$ fornece a fundamentação pedagógica para compreender a supervisão compartilhada ao censurar a "educação bancária", ou seja, a educação enquanto um ato de depositar, em que os educandos são os depositários de valores e conhecimentos e o educador é o depositante.

Freire diferencia a visão bancária de educação, que dá a permanência do conhecimento, da visão problematizadora, que destaca a mudança, onde "educadores e educandos se fazem sujeitos do seu processo, superando o intelectualismo alienante, autoritarismo do educador 'bancário' e também a falsa consciência do mundo" (Freire ${ }^{(27)}$ p. 86).

"Desta maneira, o educador já não é o que apenas educa, mas o que, enquanto educa, é educado, em diálogo com o educando que, ao ser educado, também educa. Ambos, assim, se tornam sujeitos do processo em que crescem juntos e em que os 'argumentos de autoridade' já não valem. (...) Em lugar de serem recipientes dóceis dos depósitos, são agora investigadores críticos, em diálogo com o educador, investigador crítico também". (Freire ${ }^{(27)}$, p. 97).

Considera-se que as premissas de supervisão compartilhada relacionam-se ao pensamento do referido autor e podem atender de forma mais adequada à expectativa de sustentabilidade e abrangência das ações no âmbito da ESF. 


\subsection{O AGENTE COMUNITÁRIO DE SAÚDE E A SUPERVISÃO REALIZADA PELO ENFERMEIRO.}

O ACS é um profissional proveniente da comunidade em que trabalha, conhecedor da realidade local, que atua na promoção da saúde e prevenção da doença. É o elo entre as necessidades de saúde da população e o que pode ser feito para melhorar suas condições de vida. É a ponte entre a comunidade e os profissionais do serviço de saúde ${ }^{(28)}$.

Segundo Portaria oㅡ 2.488, de 21 de outubro de $2011^{(25)}$ estão entre as atribuições do ACS:

- Trabalhar com adscrição de famílias em base geográfica definida, a micro área;

- Cadastrar e manter atualizados cadastros de todas as pessoas de sua micro área;

- Acompanhar, por meio de visitas domiciliares programadas, todas as famílias e indivíduos sob sua responsabilidade, sendo a frequência das visitas, baseada em critérios de risco e vulnerabilidade;

- Desenvolver ações para integração entre equipe e população adscrita;

- Desenvolver atividades de promoção da saúde, de prevenção das doenças e agravos e de vigilância à saúde, por meio de visitas domiciliares e de ações educativas individuais e coletivas nos domicílios e na comunidade.Para exercer com competência essas e demais atribuições, recomenda-se que ACS seja treinado, orientado e acompanhado permanentemente ${ }^{(29)}$.

A capacitação do ACS se dá em serviço, e é importante ressaltar, que muitas vezes estes não trazem em sua bagagem o ensino formal, já que o Ministério da Saúde estabelece como critério para a contratação, que o ACS apenas saiba ler e escrever. Sendo assim os responsáveis pelo processo de capacitação devem estar cientes da importância significativa do conhecimento cotidiano. Dessa maneira, capacitar o ACS demanda a utilização de uma metodologia que lhe possibilite sentirse sujeito do processo, fazendo com que ocorra o reconhecimento da importância do seu aprendizado ${ }^{(7)}$.

Como integrante da equipe de saúde, ao enfermeiro cabe: Estimular, promover e criar condições para o aperfeiçoamento técnico, científico e cultural dos 
profissionais de Enfermagem e outros membros da equipe sob sua orientação e supervisão ${ }^{(30)}$.

Assim considera-se que o enfermeiro é fundamentalmente um educador, ao capacitar a equipe sob sua liderança, para contribuir com a melhoria da qualidade da assistência à população e também por desenvolver outras tarefas no seu cotidiano ao se deparar com a necessidade de ensinar o usuário, sua família e a comunidade.

Porém a supervisão traz em si questões contraditórias relacionadas, por um lado, ao caráter de cobrança e do controle e, por outro lado, da colaboração-e da dimensão pedagógica, a qual contribui para o crescimento do supervisionado.

Enquanto alguns profissionais oscilam entre o exercício do controle e prática emancipatória, alguns autores ainda observam a forte influência das teorias clássicas da administração nessa e em outras atividades de parte dos enfermeiros. Dados apontam que a relação de poder ainda é presente nesse processo, onde o enfermeiro faz uso do poder hierárquico para fiscalizar e controlar o trabalho do ACS. Para alguns enfermeiros, o poder é ferramenta de coerção para alcance de metas e objetivos propostos ${ }^{(7,31)}$.

Assim, ainda encontramos limites quanto ao entendimento da supervisão como processo educativo que permite mudança nas relações de trabalho, nas relações com a comunidade, na reflexão acerca do modelo assistencial ${ }^{(7)}$.

Diante dessa conjuntura, mostra-se coerente e oportuno refletir sobre supervisão do ACS pelo enfermeiro e suas singularidades na ESF.

\subsection{INSTRUMENTO PARA NORTEAR A SUPERVISÃO.}

A informação em saúde é essencial para o conhecimento da realidade socioeconômica e epidemiológica local, servindo de apoio ao processo decisório e planejamento da gestão em saúde no SUS. Para tanto, se faz necessário que as informações produzidas a partir dos dados coletados sejam de qualidade e conveniente para o uso pela gestão, a fim de produzir um cuidado adequado ${ }^{(32)}$.

Buscando garantir a qualidade dos dados coletados e informações produzidas na Atenção Primária à Saúde (APS), o Sistema de Informação da Atenção Básica 
(SIAB) foi implantado para o acompanhamento das ações e dos resultados das atividades realizadas pelas equipes do Programa Saúde da Família. O SIAB foi desenvolvido como instrumento gerencial dos Sistemas Locais de Saúde e incorporou em sua formulação conceitos como território, problema e responsabilidade sanitária. Através dele obtêm-se informações sobre cadastros de famílias, condições de moradia e saneamento, situação de saúde, produção e composição das equipes de saúde. Principal instrumento de monitoramento das ações do Programa Saúde da Família ${ }^{(32)}$

O SIAB foi remodelado recentemente e nessa nova versão recebe o nome de e-SUS Atenção Básica (e-SUS $A B$ ) é uma estratégia para reestruturar as informações da saúde na Atenção Básica em nível nacional, garantindo a integração dos diversos pontos da rede de atenção. A estratégia e-SUS faz referência ao processo de informatização qualificada do SUS em busca de um SUS eletrônico ${ }^{(33)}$.

Esse novo sistema trouxe como premissas: a redução do trabalho de coleta de dados; a individualização do registro; a produção de informação integrada; o cuidado centrado no indivíduo, família, comunidade e território; e o desenvolvimento orientado pelas demandas dos usuários da saúde ${ }^{(34)}$.

A enfermeira em seu trabalho de supervisão se utiliza dos impressos que alimentam os Sistemas de Informação para realizar o controle de visitas domiciliares, avaliação do trabalho realizado pelo trabalhador e a cobrança de produção mensal. Espera-se que os dados dos Sistemas de informação sejam interpretados pelos enfermeiros na perspectiva da realização do trabalho pelo ACS e não de tarefas cumpridas $^{(7,31)}$.

Para Silva ${ }^{(7)}$, a avaliação do trabalho do ACS deve ocorrer tanto de forma quantitativa tomando como base os Sistemas de Informação, quanto qualitativa, cabendo à enfermeira avaliar a atuação do ACS tendo em vista o envolvimento com a comunidade, as facilidades e dificuldades encontradas para o desempenho da sua função. $O$ autor também aponta como um desafio para sistematizar a supervisão a criação de um instrumento para registro, de modo a subsidiar a avaliação da supervisão e possibilitar um feedback.

No entanto, os enfermeiros influenciados pelo modelo hegemônico de atenção, criam instrumentos pautados em tecnologias duras a serem preenchidos pelos ACS para realizar a supervisão. A visão de supervisão pautada pelo poder hierárquico, com único intuito de alcançar resultados quantitativos precisa ser 
repensada e dar espaço a novas formas de se organizar o trabalho tendo em vista estimular e potencializar a atuação do trabalhador e o exercício do seu autogoverno (31)

Com base no exposto supõe-se que as modalidades de supervisão em enfermagem e os instrumentos adotados ainda hoje, correspondam mais frequentemente às teorias administrativas clássicas, sendo insuficientes para levantar, acompanhar e amparar questões de natureza subjetivas e complexas inerentes ao processo e as relações de trabalho em saúde e em enfermagem.

Nesse contexto é propósito desse trabalho elaborar e validar conteúdo de um Instrumento norteador de Supervisão do trabalho do ACS ( ISACS) pelo enfermeiro baseado em uma prática administrativa mais aberta, flexível, participativa e inovadora. 



\section{OBJETIVO}

Elaborar e validar conteúdo de instrumento norteador para a supervisão do agente comunitário de saúde pelo enfermeiro na lógica participativa e colaborativa.

\subsection{OBJETIVOS ESPECÍFICOS}

- $\quad$ Elaborar proposta de instrumento norteador de supervisão do trabalho do ACS pelo enfermeiro;

- $\quad$ Caracterizar comitê de especialistas do estudo quanto a características demográficas e profissionais;

- Validar conteúdo de instrumento norteador de supervisão do trabalho do ACS pelo enfermeiro. 



\section{MÉTODO}

Trata-se de uma pesquisa qualitativa, exploratória e descritiva em duas fases. A primeira refere-se à elaboração do ISACS, a partir de levantamento bibliográfico. A segunda fase, correspondente a validação de conteúdo do ISACS, por meio da aplicação da técnica Delphi (Figura 3.2).

Para o levantamento de produções bibliográficas que fundamentem a elaboração do ISACS buscou-se por artigos com base nos seguintes crítérios:

- $\quad$ Publicados no período entre 1994 a 2017.

- Nas seguintes bases de dados eletrônicas:

MEDLINE (http://www.ncbi.nlm.nih.gov/PubMed/),

SciELO (http://www.scielo.org)

LILACS (http://lilacs.bvsalud.org/)

- Documentos publicados pelo Departamento de Atenção Básica/Ministério da Saúde,

- Em português ou inglês,

Com utilização dos seguintes descritores e termos a eles relacionados: Saúde da Família, Agente Comunitário de Saúde, Enfermeiras e Enfermeiros, Supervisão de Enfermagem, selecionados após consulta ao DeCS (Descritores em Ciências da Saúde, Bireme). Para combinar cada descritor com seus respectivos termos foi utilizado o operador lógico "OR". Para combinar dois ou três descritores/termos relacionados foi adotado o operador lógico "AND".

A validação de conteúdo do ISACS foi realizada, por meio da aplicação da técnica Delphi. Essa "debruça-se sobre o julgamento de um grupo de especialistas consistindo essencialmente em questioná-los sobre questões ou assuntos específicos" Willians e Weeb, p. 181. ${ }^{(35)}$

Para Spínola ${ }^{(36)}$ a técnica Delphi é usada, em especial quando há falta de acordo ou há conhecimentos incompletos sobre determinado assunto, geralmente de natureza técnico-científica.

Silva e Tanaka ${ }^{(37)}$ destacam a utilização da técnica na área de educação médica e de enfermagem para selecionar competências, definir objetivos e conteúdos de cursos e disciplinas. Faro ${ }^{{ }^{(38)}}$ acrescenta que a técnica Delphi 
tem sido adotada na área de enfermagem para validação de condutas e diagnósticos.

Segundo Vasconcellos e Almeida ${ }^{(39)}$ o processo de julgamento dos especialistas inicia-se a partir de um interrogatório individual quanto a aspectos ou itens de interesse. Obtêm-se, desse modo, um conjunto de respostas que amparam reformulação de itens e realização de um novo interrogatório. Os especialistas deverão, a seguir, indicar sua concordância ou não em relação aos itens reformulados. Segundo Silva e Tanaka ${ }^{(37)}$ o processo deve ser repetido até o consenso ser alcançado.

Destaca-se que o nível de consenso é determinado pelo pesquisador, assim como a quantidade de interrogatórios e esses dependerão da natureza do problema a ser investigado, seus determinantes, previsão de tempo e de custo. Faro, ${ }^{(38)}$ aponta variação nos níveis de concordância que se estendem de $50 \%$ a $80 \%$. Segundo Williams, Webb ${ }^{(35)}$ e Spínola ${ }^{(36)}$ importantes pesquisas que desenvolveram a técnica Delphi, inclusive na área de saúde, trabalham com o índice de concordância de 0,70 ou $70 \%$. No que se refere ao número de interrogatórios, salienta-se que o processo é usualmente repetido três vezes ${ }^{(40,41)}$

Quanto ao número de especialistas ou juízes e critérios para sua seleção, ficam determinados diretamente ao fenômeno que se pretende estudar.

Segundo Pasquali ${ }^{(42)}$ quando ouvimos a opinião de membros da população ao qual o instrumento se destina e peritos na área, estaremos conduzindo a análise sobre a compreensão dos itens e sua pertinência, respectivamente. A análise de pertinência pode ser chamada validação de conteúdo.

Assim, a técnica Delphi constitui-se como estratégia apropriada para estabelecer validade de conteúdo de instrumentos, por permitir ouvir e analisar, de forma sistemática, opiniões de especialistas com possibilidade de gerar no final dessa análise um produto validado ${ }^{(38)}$.

No presente estudo, "Elaboração e validação de um instrumento norteador de supervisão de ACS por enfermeiros na lógica participativa e colaborativa" O ISACS foi elaborado em sua versão preliminar pelos pesquisadores como base em pesquisa bibliográfica. A seguir, para validar 0 
conteúdo do ISACS, empregou-se a técnica Delphi em 2 etapas: $1^{\text {an}}$ ) interrogatório, obtenção de respostas dos especialistas em relação a versão preliminar e, elaboração da $1^{\text {a }}$ versão ajustada; $2^{\underline{a}}$ interrogatório, obtenção de respostas e elaboração de versão consensuada do ISACS.

\subsection{LOCAL DO ESTUDO}

Sorocaba é um município do interior do estado de São Paulo, é a quarta mais populosa cidade do interior e a mais populosa da região sul paulista, com uma população de 659871 habitantes, estimada pelo IBGE em $2017^{(43)}$.

A cidade possui 32 unidades básicas de saúde (UBS), dessas, 18 atuam segundo o modelo tradicional, 01 Unidade conta com Programa de Agentes Comunitários de Saúde (PACS), 13 Unidades funcionam segundo o modelo da Estratégia de Saúde da Família (ESF).

Atualmente para fins de gerenciamento e planejamento, o município trabalha com 3 regionais de saúde (Figura 3.1), que estão divididas em: Regionais de Saúde Oeste (verde no mapa); Regional de Saúde Norte (amarelo no mapa) e Regional de Saúde Sudeste (azul no mapa).

Figura 3.1 - Unidades de Saúde, Regionais de Saúde e Território de Abrangência ${ }^{(44)}$

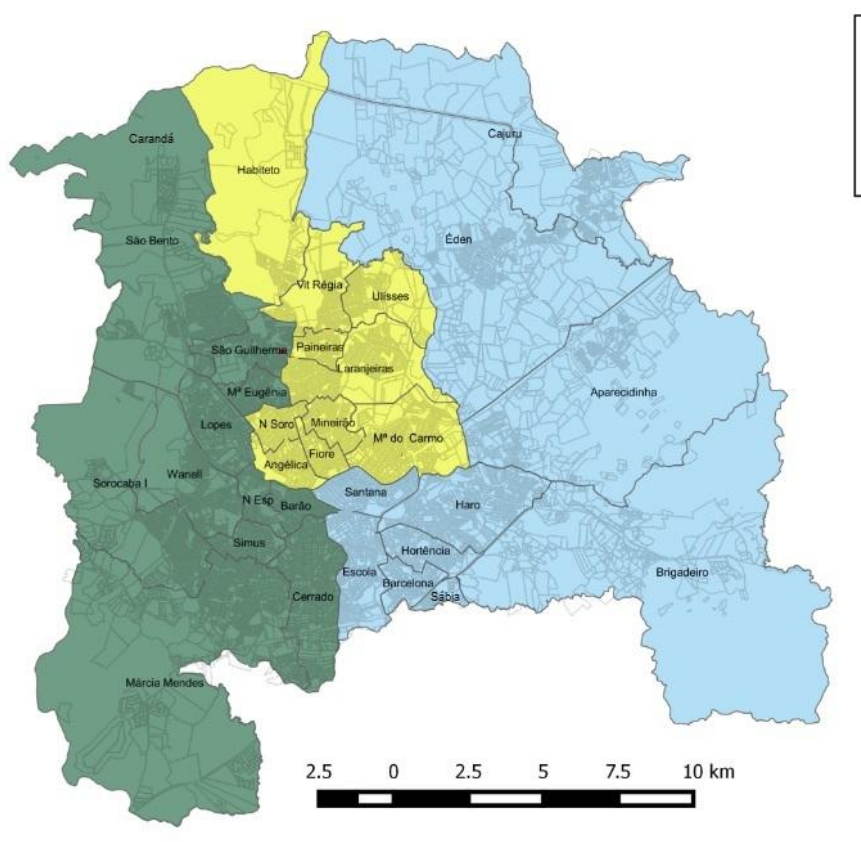




\subsection{POPULAÇÃO}

Para validação doo conteúdo do ISACS, elaborado em sua versão preliminar pelas pesquisadoras, foi necessário compor um painel de especialistas, seguindo-se os pressupostos da técnica Delphi. Com essa finalidade, foram adotados os seguintes critérios de inclusão.

Critérios de inclusão:

1. Serem enfermeiros;

2. Em atuação na Estratégia Saúde da Família por um período igual ou superior há 2 anos;

3. Atuantes no município de Sorocaba;

4. Com interesse expresso em colaborar com o estudo.

A partir de cadastro de profissionais, fornecido pela Secretaria Municipal de Saúde de Sorocaba e dos critérios, estimou-se a participação de 35 enfermeiras no estudo.

\subsection{COLETA DE DADOS}

Os enfermeiros foram convidados (Apêndice B e E) a participar do estudo - por meio de correio eletrônico, e solicitarei informações profissionais a fim de caracterizar o grupo de especialistas.

No que se refere especificamente ao ISACS, foi solicitado aos especialistas que opinem individual e confidencialmente sobre o mesmo seguindo as etapas previstas para o estudo Delphi.

Na primeira etapa do estudo Delphi, foi elaborado um questionário de opinião - com característica exploratória (Apêndice C), objetivando gerar novos itens, excluir ou modificar os existentes na versão preliminar do ISACS. O julgamento dos especialistas foi apreendido por meio de escala de opinião de 5 (cinco) pontos e por meio de comentários e sugestões. Aos especialistas foi fortemente recomendado que emitissem comentários e sugestões. Essas contribuições ao ISACS, quando pertinentes aos objetivos previstos para 0 
mesmo, independente o nível de concordância, foram incorporadas e compuseram sua $1 \underline{\underline{a}}$ versão ajustada.

$\mathrm{Na} 2^{\mathrm{a}}$ etapa do estudo Delphi, foi obtido o julgamento dos especialistas em relação ao ISACS quanto ao conteúdo e enunciado dos itens (Apêndice F). Com base no nível de consenso de $80 \%$, estabelecido no presente estudo, os itens do ISACS que foram aprovados em seu conteúdo e linguagem por $80 \%$ ou mais especialistas foram mantidos; Itens que fossem reprovados em seu conteúdo por mais de $20 \%$ dos juízes seriam excluídos e itens reprovados por mais de $20 \%$ quanto à linguagem seriam modificados, porem nenhum item foi excluído ou modificado, pois foram aprovados em seu conteúdo e linguagem por mais de $80 \%$ dos especialistas. Assim embora prevista, não houve a necessidade de realizar a $3^{\underline{a}}$ etapa do estudo, sendo a versão consensuada do ISACS obtida na $2^{\underline{a}}$ etapa.

Figura 3.2 - Representação da elaboração do instrumento pela técnica Delphi

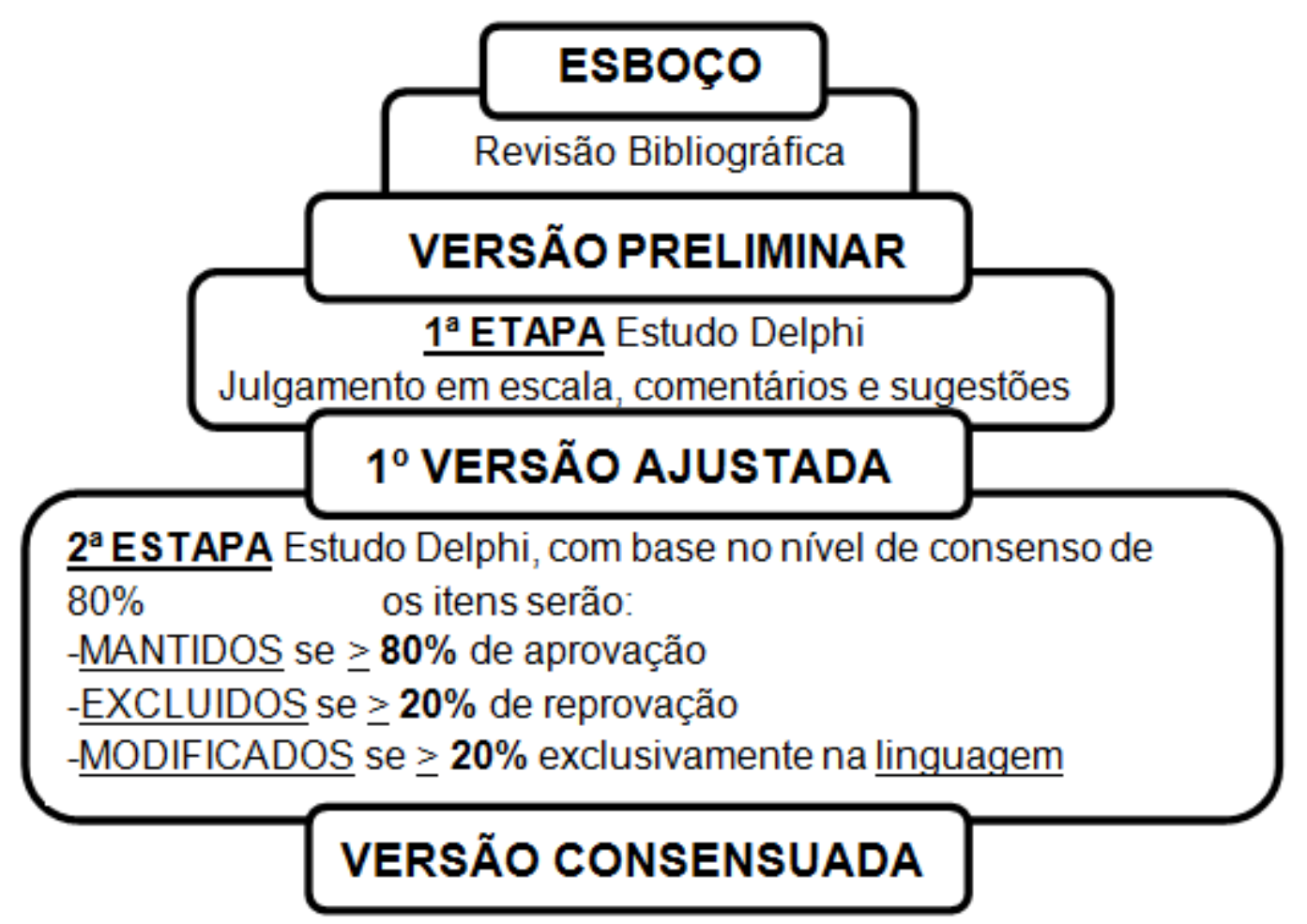



Com base em levantamento bibliográfico foi possível elaborar a versão preliminar do Instrumento (APÊNDICE G) a ser posteriormente submetido a julgamento pelos especialistas. O referido levantamento sobre o tema foi realizado nas bases de dados e a partir dele foram encontrados 46 artigos. Após a aplicação do critério "ano de publicação", foram selecionados 34 artigos. Destes, 02 artigos estavam duplicados, sendo mantida a versão do artigo abrigada na base de dados mais abrangente, restando, portanto, 32 artigos para leitura dos títulos e resumos. A partir destes foram selecionados 25 artigos para a leitura na íntegra.

A partir da leitura na íntegra, 08 artigos foram excluídos por não corresponderem ao tema de interesse do estudo. Foram selecionados, portanto, para a revisão bibliográfica, 17 artigos, sendo estes mapeados segundo: características principais da publicação (Quadro 4.2).

Quadro 4.2 - Mapeamento dos artigos em relação ao título do periódico, autores, ano de publicação e idioma. São Paulo, 2018

\begin{tabular}{|c|c|c|c|c|}
\hline Título do Artigo & $\begin{array}{c}\text { Título do } \\
\text { Periódico }\end{array}$ & Autores & $\begin{array}{c}\text { Ano de } \\
\text { Publicação }\end{array}$ & Idioma \\
\hline $\begin{array}{c}\text { Atividades } \\
\text { gerenciais do } \\
\text { enfermeiro no } \\
\text { monitoramento } \\
\text { das visitas } \\
\text { domiciliares do } \\
\text { agente } \\
\text { comunitário de } \\
\text { saúde }\end{array}$ & $\begin{array}{c}\text { Arquivo de } \\
\text { Ciências da } \\
\text { Saúde } \\
\text { Unipar, V.22 }\end{array}$ & $\begin{array}{c}\text { Ribiro GRMS, Graça } \\
\text { BC, Nascimento VF, } \\
\text { Hattori TY, Gleriano } \\
\text { JS, Terças-Trettel } \\
\text { ACP. }\end{array}$ & 2018 & Português \\
& & & & \\
\hline
\end{tabular}




\begin{tabular}{|c|c|c|c|c|}
\hline Título do Artigo & $\begin{array}{l}\text { Título do } \\
\text { Periódico }\end{array}$ & Autores & $\begin{array}{c}\text { Ano de } \\
\text { Publicação }\end{array}$ & Idioma \\
\hline $\begin{array}{c}\text { Supervisão dos } \\
\text { Agentes } \\
\text { Comunitários } \\
\text { de Saúde na } \\
\text { Estratégia Saúde } \\
\text { da } \\
\text { Família: a ótica } \\
\text { dos enfermeiros }\end{array}$ & $\begin{array}{c}\text { Revista da } \\
\text { Escola de } \\
\text { Enfermagem da } \\
\text { USP, V.48 }\end{array}$ & $\begin{array}{c}\text { Silva JS, } \\
\text { Fortuna CM, } \\
\text { Pereira MJB, } \\
\text { Matumoto S, } \\
\text { Santana FR, } \\
\text { Marciano FM, } \\
\text { Silva JB, } \\
\text { Ferreira M, } \\
\text { Mishima SM. }\end{array}$ & 2014 & Português \\
\hline $\begin{array}{c}\text { A incorporação } \\
\text { da busca ativa de } \\
\text { sintomáticos } \\
\text { respiratórios para } \\
\text { o controle da } \\
\text { tuberculose na } \\
\text { prática do agente } \\
\text { comunitário de } \\
\text { saúde }\end{array}$ & $\begin{array}{c}\text { Ciência \& } \\
\text { Saúde Coletiva, } \\
\text { V.10 }\end{array}$ & $\begin{array}{l}\text { Muniz JN, } \\
\text { Palha PF, } \\
\text { Monroe AA, } \\
\text { Gonzales RC, } \\
\text { Ruffino AR, } \\
\text { Villa TCS. }\end{array}$ & 2005 & Português \\
\hline $\begin{array}{l}\text { A supervisão do } \\
\text { agente } \\
\text { comunitário de } \\
\text { saúde: limites e } \\
\text { desafios para a } \\
\text { enfermeira }\end{array}$ & $\begin{array}{c}\text { ENSP - } \\
\text { Dissertações de } \\
\text { Mestrado }\end{array}$ & $\begin{array}{l}\text { Silva ABF, } \\
\text { Hortale.VA. }\end{array}$ & 2002 & Português \\
\hline $\begin{array}{l}\text { The evolution of } \\
\text { the Community } \\
\text { Health Worker } \\
\text { program in Papua } \\
\text { New Guinea }\end{array}$ & $\begin{array}{c}\text { Rural and } \\
\text { Remote Health, } \\
\text { V.17 }\end{array}$ & $\begin{array}{c}\text { Pilang CL, } \\
\text { Gray,MA, } \\
\text { Oprescu FI. }\end{array}$ & 2017 & Inglês \\
\hline $\begin{array}{l}\text { Programa Saúde } \\
\text { da Família: } \\
\text { supervisão ou } \\
\text { “convisão”? } \\
\text { Estudo de caso } \\
\text { em município de } \\
\text { médio porte }\end{array}$ & $\begin{array}{c}\text { Caderno de } \\
\text { Saúde Pública, } \\
\text { V.20 }\end{array}$ & $\begin{array}{l}\text { Reis CCL, } \\
\text { Hortale VA. }\end{array}$ & 2004 & Português \\
\hline
\end{tabular}




\begin{tabular}{|c|c|c|c|c|}
\hline Título do Artigo & $\begin{array}{l}\text { Título do } \\
\text { Periódico }\end{array}$ & Autores & $\begin{array}{c}\text { Ano de } \\
\text { Publicação }\end{array}$ & Idioma \\
\hline $\begin{array}{c}\text { Supervisão de } \\
\text { enfermagem para } \\
\text { a integralidade do } \\
\text { cuidado }\end{array}$ & $\begin{array}{c}\text { Revista } \\
\text { Brasileira de } \\
\text { Enfermagem, } \\
\text { V.70 }\end{array}$ & $\begin{array}{c}\text { Chaves LDP, } \\
\text { Mininel VA, Silva } \\
\text { JAM, Alves LR, Silva } \\
\text { MF, Camelo SHH. }\end{array}$ & 2017 & Português \\
\hline $\begin{array}{c}\text { A prática } \\
\text { gerencial do } \\
\text { enfermeiro no } \\
\text { PSF na } \\
\text { perspectiva da } \\
\text { sua ação } \\
\text { pedagógica } \\
\text { educativa: uma } \\
\text { breve reflexão }\end{array}$ & $\begin{array}{c}\text { Ciência \& } \\
\text { Saúde Coletiva, } \\
\text { V.13 }\end{array}$ & $\begin{array}{l}\text { Villas Bôas LMF.M, } \\
\text { Araújo MBS, } \\
\text { Timóteo RPS. }\end{array}$ & 2008 & Português \\
\hline $\begin{array}{l}\text { Processo de } \\
\text { Trabalho em } \\
\text { Unidade de Saúde } \\
\text { da Família e a } \\
\text { Educação } \\
\text { Permanente }\end{array}$ & $\begin{array}{l}\text { Trabalho } \\
\text { Educação e } \\
\text { Saúde, V.14 }\end{array}$ & $\begin{array}{l}\text { Rebecca SRS, } \\
\text { Caldas LBSN, } \\
\text { Falcão MLP, } \\
\text { Goes PSA. }\end{array}$ & 2016 & Português \\
\hline $\begin{array}{l}\text { A supervisão do } \\
\text { enfermeiro no } \\
\text { trabalho do } \\
\text { agente } \\
\text { comunitário de } \\
\text { saúde: uma } \\
\text { revisão } \\
\text { bibliográfica }\end{array}$ & $\begin{array}{l}\text { Biblioteca } \\
\text { Digital da } \\
\text { Faculdade de } \\
\text { medicina da } \\
\text { UFMG }\end{array}$ & $\begin{array}{l}\text { Costa MAO, } \\
\text { Araujo MRN. }\end{array}$ & 2011 & Português \\
\hline $\begin{array}{l}\text { Supervisão em } \\
\text { Enfermagem: } \\
\text { Instrumento } \\
\text { administrativo } \\
\text { para o trabalho da } \\
\text { equipe de saúde }\end{array}$ & $\begin{array}{l}\text { In } 13^{\circ} \\
\text { Congresso } \\
\text { Brasileiro dos } \\
\text { Conselhos de } \\
\text { Enfermagem } \\
\text { (CBCENF) }\end{array}$ & $\begin{array}{l}\text { Santos NM. } \\
\text { Lima ET, } \\
\text { Pinto RNM, } \\
\text { Andrade LDF. }\end{array}$ & 2010 & Português \\
\hline
\end{tabular}




\begin{tabular}{|c|c|c|c|c|}
\hline Título do Artigo & $\begin{array}{l}\text { Título do } \\
\text { Periódico }\end{array}$ & Autores & $\begin{array}{c}\text { Ano de } \\
\text { Publicação }\end{array}$ & Idioma \\
\hline $\begin{array}{l}\text { O processo de } \\
\text { trabalho do } \\
\text { enfermeiro na } \\
\text { supervisão ao } \\
\text { agente } \\
\text { comunitário de } \\
\text { saúde em equipes } \\
\text { de Saúde da } \\
\text { Família }\end{array}$ & $\begin{array}{c}\text { Biblioteca } \\
\text { Digital de Teses } \\
\text { e Dissertações } \\
\text { da USP. }\end{array}$ & $\begin{array}{l}\text { Silva JS, } \\
\text { Fortuna CM. }\end{array}$ & 2014 & Português \\
\hline $\begin{array}{l}\text { Supervisão em } \\
\text { Enfermagem } \\
\text { como progresso } \\
\text { educativo: limites } \\
\text { e possibilidades. }\end{array}$ & $\begin{array}{c}\text { Biblioteca } \\
\text { Digital de Teses } \\
\text { e Dissertações } \\
\text { da Universidade } \\
\text { Federal de } \\
\text { Santa Catarina }\end{array}$ & $\begin{array}{l}\text { Rabello T, } \\
\text { Saupe R. }\end{array}$ & 2002 & Português \\
\hline $\begin{array}{c}\text { Perfil do } \\
\text { enfermeiro } \\
\text { atuante na } \\
\text { estratégia saúde } \\
\text { da família }\end{array}$ & $\begin{array}{l}\text { Ciência Cuido } \\
\text { e Saúde, V.8 }\end{array}$ & $\begin{array}{c}\text { Silva C, } \\
\text { Ramos C S, } \\
\text { Ceolin RMHT, } \\
\text { Dilélio AS, } \\
\text { Facchini LA. }\end{array}$ & 2009 & Português \\
\hline $\begin{array}{c}\text { Trabalho do } \\
\text { Agente } \\
\text { Comunitário de } \\
\text { Saúde: a } \\
\text { dimensão } \\
\text { educativa da } \\
\text { supervisão } \\
\end{array}$ & $\begin{array}{l}\text { Sociedade em } \\
\text { Debate, V.17 }\end{array}$ & $\begin{array}{c}\text { Trapé CA, } \\
\text { Soares CB, } \\
\text { Dalmaso ASW. }\end{array}$ & 2011 & Português \\
\hline $\begin{array}{l}\text { Utilização do } \\
\text { Documento } \\
\text { Norteador pelos } \\
\text { Enfermeiros nas } \\
\text { Ações do Agente } \\
\text { Comunitário de } \\
\text { Saúde }\end{array}$ & $\begin{array}{c}\text { Biblioteca } \\
\text { Digital Brasileira } \\
\text { de Teses e } \\
\text { Dissertações } \\
\text { (BDTD) }\end{array}$ & $\begin{array}{c}\text { Souza AL, } \\
\text { Ramos LH, } \\
\text { Figueiredo EM. }\end{array}$ & 2010 & Português \\
\hline
\end{tabular}




\begin{tabular}{|c|c|c|c|c|}
\hline Título do Artigo & $\begin{array}{l}\text { Título do } \\
\text { Periódico }\end{array}$ & Autores & $\begin{array}{c}\text { Ano de } \\
\text { Publicação }\end{array}$ & Idioma \\
\hline $\begin{array}{c}\text { O Genograma e o } \\
\text { Ecomapa } \\
\text { instrumentos } \\
\text { para } \\
\text { compreender a } \\
\text { rede familiar de } \\
\text { uma pessoa com } \\
\text { transtorno } \\
\text { mental: um } \\
\text { estudo de caso. }\end{array}$ & $\begin{array}{c}\text { Revista } \\
\text { Interdisciplinar } \\
\text { de Estudos em } \\
\text { Saúde, V.4 }\end{array}$ & $\begin{array}{c}\text { Machado RR, } \\
\text { Júnior EC, } \\
\text { Justi J. }\end{array}$ & 2016 & Português \\
\hline
\end{tabular}

No quadro 4.3 estão dispostas as contribuições da revisão bibliográfica para a elaboração da versão preliminar do instrumento quanto aos itens e os aspectos contemplados.

Quadro 4.3 - Contribuições da revisão bibliográfica para a elaboração da versão preliminar do instrumento. São Paulo, 2018

\begin{tabular}{|c|c|}
\hline Itens & Aspectos contemplados \\
\hline Produtividade & $\begin{array}{c}\text { Caracterização da micro área: Numero de famílias, } \\
\text { número de visitas }\end{array}$ \\
\hline Vigilância em saúde & $\begin{array}{c}\text { Dados referentes aos grupos específicos (Crianças, } \\
\text { mulheres, idosos acamados, etc.), total de visitas } \\
\text { realizadas a esses grupos específicos. } \\
\text { Famílias de risco }\end{array}$ \\
\hline $\begin{array}{c}\text { Caracterização de uma família } \\
\text { visitada: ações a serem } \\
\text { desenvolvidas }\end{array}$ & $\begin{array}{c}\text { Estrutura familiar (Genograma), Relação dos } \\
\text { membros da família com outros sistemas } \\
\text { (Ecomapa), questões de saúde da família, ações em } \\
\text { saúde e/ou intersetoriais a serem desenvolvidas na } \\
\text { família. }\end{array}$ \\
\hline $\begin{array}{c}\text { Dificuldades e Problemas } \\
\text { identificados no território: ações } \\
\text { propostas }\end{array}$ & $\begin{array}{l}\text { As principais dificuldades identificadas pelo ACS no } \\
\text { período; os principais problemas diagnosticados } \\
\text { pelo ACS na visita domiciliar; os problemas } \\
\text { identificados pela enfermeira na supervisão e as } \\
\text { ações propostas pelo enfermeiro e ACS para } \\
\text { redução dos problemas identificados. }\end{array}$ \\
\hline
\end{tabular}




\begin{tabular}{|c|c|}
\hline Itens & Aspectos contemplados \\
\hline $\begin{array}{c}\text { Acompanhamento e avaliação } \\
\text { das ações }\end{array}$ & $\begin{array}{c}\text { Acompanhamento/avaliação das ações propostas } \\
\text { pelo enfermeiro e ACS }\end{array}$ \\
\hline Educação em saúde & $\begin{array}{c}\text { Propostas elaboradas para a qualificação do } \\
\text { trabalho do ACS, voltadas à educação em saúde. }\end{array}$ \\
\hline
\end{tabular}

O levantamento bibliográfico foi fundamental para a elaboração da versão preliminar ISACS. Conforme ilustra o Quadro 4.3;

O primeiro item aborda a produtividade, no que se refere ao número de famílias, o número de pessoas e o número de visitas realizadas, dados fundamentais para caracterizar a área, porém aborda também o total de dias trabalhados e as ocorrências que influenciaram o número de dias trabalhados nesse período.

A opção pela inclusão desse item e aspectos nele contemplados apoiam-se basicamente nos artigos de Silva ${ }^{(7)}$ e Silva et al ${ }^{(45)}$. Segundo Silva et $\mathrm{al}^{(45)}$ uma das formas mais utilizadas pelo enfermeiro para conhecer 0 território são os dados apresentados pelos ACS após as visitas realizadas, esses dados contribuem para traçar o perfil da população atendida bem como quantificam o trabalho do ACS, porém, conforme Silva ${ }^{(7)}$ quando falamos em produtividade não podemos somente analisar friamente os números, devemos olhar além, compreender todas as informações imbuídas nesses números, pois a supervisão do trabalho do ACS deve sim ocorrer de forma quantitativa, mas principalmente de forma qualitativa.

O segundo item previsto no ISACS refere-se à vigilância em saúde. Segundo Santos et al ${ }^{(46)}$ o principal propósito da supervisão é a qualificação da assistência prestada ao usuário, a assistência, por sua vez, é norteada pela vigilância em saúde, por meio da qual os dados coletados são processados, analisados e transformados em informação. Sendo assim abordar no instrumento aspectos de vigilância em saúde nos permite planejar atividades, com base no conhecimento do diagnóstico das necessidades da população a ser assistida. 
O ISACS, em sua versão preliminar também traz como item a Caracterização de uma família visitada: ações a serem desenvolvidas, que e dá por meio da aplicação do genograma e ecomapa. A inclusão dessas ferramentas no instrumento de supervisão visa permitir ao ACS expor seu conhecimento sobre determinada família, mapeá-la bem como suas interações. Segundo Silva ${ }^{(47)}$ a descrição, a compreensão e o acompanhamento da rede familiar, aprimoram o trabalho da equipe e para alcance dessa finalidade os autores propõem justamente 0 uso de genograma e ecomapa. Esses dispositivos foram desenvolvidos pelas enfermeiras canadenses Lorraine $M$. Wright e Maureen Leahey por intermédio do Modelo Calgary de Avaliação da Família, que, por sua vez, consiste num mapeamento da estrutura familiar, fornecendo informações importantes, que possibilitam a realização de um estudo dos vínculos estabelecidos entre o indivíduo, sua família e o meio em que vive e/ou no qual foi inserido ${ }^{(48)}$.

O quarto item do instrumento, aborda as Dificuldades e Problemas identificados no território: ações propostas. Segundo Santos et al $^{(46)}$ e Rabello $^{(49)}$ variados são os problemas e dificuldades encontrados na atuação do ACS, cabe ao enfermeiro durante a supervisão dar suporte assumindo uma postura motivadora de orientação e instrução do trabalho do ACS, através de encontros, momentos de troca de saberes e práticas de acolhimento, e, essencialmente, momentos de construção coletiva.

O próximo item do Instrumento discorre sobre Acompanhamento e avaliação das ações. De acordo com Silva ${ }^{(31)}$, Bôas et $\mathrm{al}^{(50)}$ e Costa ${ }^{(51)}$, para o enfrentamento das dificuldades, recomenda-se: planejar, estabelecer metas, monitorar esse processo e posteriormente avaliar, e para que seja possível acompanhar essas etapas, sugerem a criação de um instrumento para o registro das avaliações do trabalho do ACS como complemento na sistematização da supervisão do ACS.

Para Gama e Sanhudo ${ }^{(52)}$ a avaliação da supervisão deve ser realizada pelo enfermeiro de forma contínua, revendo sempre o planejamento inicial e replanejando de acordo com a necessidade, uma vez que é um meio e não um fim em si mesma, devendo estar voltada para a caracterização dos resultados obtidos, adequação das propostas e sua praticidade. A avaliação pode ser imediata (realizada ao longo do processo, ao final de todas as ações, 
permitindo a análise dos resultados obtidos, a pertinência dos objetivos e das ações, técnicas e instrumentos usados e caracterizando a sua flexibilidade) e mediata (realizada ao final de todo o processo, para esclarecer as dúvidas que tenham surgido e replanejar com nova direção de orientação para as ações).

O ultimo item do Instrumento trata de educação em saúde, um espaço de ensino-aprendizagem, participativo e critico reflexivo, onde a apropriação de saberes e conhecimentos ofereçam subsídios necessários na complexidade da atenção aos usuários ${ }^{(53)}$.

Tal qual Trape ${ }^{(54)}$ a prática educativa caracteriza uma supervisão emancipatória com capacidade de integrar as atividades, ativar mecanismos de compreensão do processo de trabalho, atuando como instrumento de reflexão, de construção do conhecimento e de resolução conjunta dos problemas.

Para Silva ${ }^{(45)}$ é evidente a necessidade de mudança e superação dos modelos de atenção e supervisão vigentes, em direção a um trabalho construído coletivamente, tendo sempre como finalidade a cooperação e o estimulo, objetivando a melhoria da assistência ao usuário. A supervisão participativa contrapõe-se a lógica da punição como forma de produção em saúde contribuindo para da implementação de ações de educação em saúde.

A versão preliminar elaborada a partir do levantamento bibliográfico foi submetida à pré-teste, visando proceder a eventuais ajustes antes de seu envio aos especialistas para julgamento. .

\subsection{PRÉ TESTE}

Para participar do pré-teste, foram selecionados dois enfermeiros que já atuaram por mais de dois anos na Estratégia Saúde da Família, no município de Sorocaba e que não se enquadravam nos critérios de inclusão do estudo por estarem atualmente em outras funções. Ambos os enfermeiros tem tempo de formação de 17 anos e especialização na área, 01 possui mestrado e atua há 18 anos na área, o outro atua há 08 anos. 
Tabela 4.1 - Pré-teste - versão preliminar

\begin{tabular}{|c|c|c|c|c|c|}
\hline Opiniões & \multicolumn{5}{|c|}{ Graus de concordância (№ e \%) } \\
\hline $\begin{array}{l}\text { Referentes à forma e ao conteúdo do } \\
\text { Instrumento }\end{array}$ & CP & C & NN & D & DP \\
\hline \multirow{2}{*}{$\begin{array}{l}\text { 1. O Instrumento foi construído de } \\
\text { modo que o enfermeiro realize uma } \\
\text { supervisão que favoreça práticas mais } \\
\text { abertas, participativas e colaborativas. }\end{array}$} & 01 & 01 & 0 & 0 & 0 \\
\hline & $50 \%$ & $50 \%$ & 0 & 0 & 0 \\
\hline \multirow{2}{*}{$\begin{array}{l}\text { 2. No que corresponde à disposição dos } \\
\text { itens o instrumento está adequado. }\end{array}$} & 0 & 02 & 0 & 0 & 0 \\
\hline & 0 & $100 \%$ & 0 & 0 & 0 \\
\hline \multirow{2}{*}{$\begin{array}{l}\text { 3. A linguagem adotada no instrumento } \\
\text { mostra-se acessível a enfermeiros e } \\
\text { ACS. }\end{array}$} & 0 & 02 & 0 & 0 & 0 \\
\hline & 0 & $100 \%$ & 0 & 0 & 0 \\
\hline \multirow{2}{*}{$\begin{array}{l}\text { 4. O instrumento contém informações } \\
\text { que são pertinentes acerca do trabalho } \\
\text { desenvolvido pelo ACS. }\end{array}$} & 0 & 02 & 0 & 0 & 0 \\
\hline & 0 & $100 \%$ & 0 & 0 & 0 \\
\hline \multirow{2}{*}{$\begin{array}{l}\text { 5. Os dados referentes á produtividade } \\
\text { são relevantes para a supervisão do } \\
\text { ACS pelo enfermeiro. }\end{array}$} & 1 & 1 & 0 & 0 & 0 \\
\hline & $50 \%$ & $50 \%$ & 0 & 0 & 0 \\
\hline \multirow{2}{*}{$\begin{array}{l}\text { 6. Os dados referentes à vigilância em } \\
\text { saúde são relevantes para a supervisão } \\
\text { do ACS pelo enfermeiro. }\end{array}$} & 0 & 02 & 0 & 0 & 0 \\
\hline & 0 & $100 \%$ & 0 & 0 & 0 \\
\hline \multirow{2}{*}{$\begin{array}{l}\text { 7. É pertinente a caracterizacão de uma } \\
\text { família em um instrumento de } \\
\text { supervisão. }\end{array}$} & 1 & 1 & 0 & 0 & 0 \\
\hline & $50 \%$ & $50 \%$ & 0 & 0 & 0 \\
\hline \multirow{2}{*}{$\begin{array}{l}\text { 8. No que se refere à caracterização de } \\
\text { uma família o propósito do instrumento } \\
\text { é contextualizar a estrutura e a } \\
\text { dinâmica familiar sua inserção social e } \\
\text { questão de saúde. }\end{array}$} & 0 & 02 & 0 & 0 & 0 \\
\hline & 0 & $100 \%$ & 0 & 0 & 0 \\
\hline \multirow{2}{*}{$\begin{array}{l}\text { 9. A caracterização de uma família } \\
\text { visitada deve ser reconstruída } \\
\text { periodicamente. }\end{array}$} & 0 & 1 & 1 & 0 & 0 \\
\hline & 0 & $50 \%$ & $50 \%$ & 0 & 0 \\
\hline
\end{tabular}


Opiniões

Graus de concordância (№ e \%)

Referentes à forma e ao conteúdo do Instrumento

10. A utilização de Genograma e Ecomapa é pertinente para contextualizar a dinâmica familiar e inserção social.

11. Os itens "dificuldades encontradas pelos ACS em relação ao trabalho no período" e "problemas identificados pelo enfermeiro e ACS na visita" estão adequados ao propósito do instrumento.

12. Os itens "acões propostas pelo enfermeiro e ACS para a redução dos problemas identificados $\mathrm{e}$ acompanhados" e "acompanhamento/avaliação das ações propostas" estão adequados aos propósitos do instrumento.

13. O item "acompanhamento e avaliação" deve ser revisto periodicamente.

14. No que se refere à educação em saúde a proposta está adequada aos propósitos do instrumento.

15. Esse instrumento mostra-se como um recurso útil na perspectiva de uma supervisão participativa e colaborativa.

\section{CP} (n)

NN

\begin{tabular}{|c|c|} 
D & DP \\
\hline 0 & 0
\end{tabular}

a

$0 \quad 02$

0

0

\begin{tabular}{|l|l|l|l} 
& & & 0 \\
\hline $100 \%$ & 0 & 0 & 0 \\
\hline
\end{tabular}

(

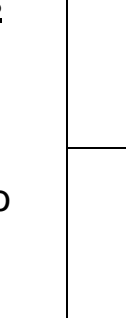

0

1

\begin{tabular}{|c|c|c|c|}
\hline 0 & $50 \%$ & 0 & $50 \%$ \\
\hline
\end{tabular}

0

.




\subsubsection{Comentários e Sugestões}

O pré-teste apresentou alto grau de concordância entre os dois enfermeiros participantes, contudo eles tecem sugestões acerca do Instrumento ISACS.

A primeira sugestão foi que para que no item vigilância em saúde seja contemplado o número de indivíduos domiciliados.

Em consonância, o Caderno de Atenção Básica ${ }^{(55)}$ refere que famílias e pessoas que necessitam de assistência domiciliar precisam ser consideradas em sua complexidade e riscos aos quais estão expostas e não apenas em seus aspectos biológicos. Ainda, segundo o Caderno de Atenção Básica ${ }^{(55)}$ é necessário diferenciar se 0 individuo tem mobilidade mesmo que com dificuldade ou se está estritamente restrito ao leito, o que contribui para uma assistência qualificada.

Outra sugestão foi à organização do ISACS por domínios o que se configura como princípio norteador para a organização de documentos e informações, conforme Campos e Gomes ${ }^{(56)}$.

Tais comentários e sugestões foram incorporados à versão preliminar do Instrumento ISACS, dada a sua relevância e pertinência para em relação as finalidades do mesmo. Após ajustes, a versão preliminar foi submetida a julgamento dos especialistas.

\subsection{ESTUDO DELPHI - ESPECIALISTAS}

Conforme critérios de inclusão no estudo estimava-se a participação de 35 enfermeiros, porém no momento em que foi encaminhada a carta convite, 03 estavam de férias, 02 de licença maternidade, 02 de licença saúde, 01 havia aposentado e 03 não se enquadravam nos critérios, pois estavam atuando na Estratégia Saúde da família a menos de 02 anos. Nove (9) potenciais participantes, embora tenham aceito o convite, não enviaram suas contribuições. Assim 15 especialistas participaram efetivamente da pesquisa, o 
que implicou em uma percentual de $65,5 \%$ do total de especialistas aptos a participar do Estudo.

\subsubsection{Caracterização profissional dos especialistas}

O Quadro 4.4 apresenta a caracterização dos especialistas do Estudo Delphi, e contempla dados como: formação em escola pública ou privada, tempo de formação, pós graduação ma área e experiência na área.

Quadro 4.4 - Caracterização profissional dos especialistas do Estudo Delphi. São Paulo, 2018

\begin{tabular}{|c|c|c|c|c|c|c|c|}
\hline \multirow[t]{2}{*}{ Especialistas } & \multicolumn{2}{|c|}{$\begin{array}{c}\begin{array}{c}\text { Formado em } \\
\text { escola... }\end{array} \\
\end{array}$} & \multirow{2}{*}{$\begin{array}{c}\text { Tempo de } \\
\text { formado } \\
\text { (anos) }\end{array}$} & \multicolumn{3}{|c|}{ Pós-graduação na área } & \multirow{2}{*}{$\begin{array}{c}\text { Experiência } \\
\text { na área } \\
\text { (em anos) }\end{array}$} \\
\hline & Privada & Pública & & Especialização & Mestrado & Doutorado & \\
\hline 01 & $\mathrm{X}$ & & 15 & & & & 08 \\
\hline 02 & $\mathrm{X}$ & & 17 & $\mathrm{X}$ & & & 08 \\
\hline 03 & $\mathrm{X}$ & & 20 & $\mathrm{X}$ & $x$ & & 16 \\
\hline 04 & & $\mathrm{X}$ & 15 & $\mathrm{X}$ & & & 03 \\
\hline 05 & $\mathrm{X}$ & & 10 & $\mathrm{X}$ & $x$ & & 08 \\
\hline 06 & $\mathrm{X}$ & & 10 & $\mathrm{X}$ & & & 09 \\
\hline 07 & $\mathrm{X}$ & & 17 & $\mathrm{X}$ & & & 15 \\
\hline 08 & $\mathrm{X}$ & & 09 & $\mathrm{X}$ & & & 04 \\
\hline 09 & & $\mathrm{X}$ & 22 & $\mathrm{X}$ & $x$ & & 06 \\
\hline 10 & & $\mathrm{X}$ & 15 & $\mathrm{X}$ & $x$ & & 10 \\
\hline 11 & $\mathrm{X}$ & & 08 & $\mathrm{X}$ & & & 04 \\
\hline 12 & $\mathrm{X}$ & & 07 & $\mathrm{X}$ & & & 04 \\
\hline 13 & $\mathrm{X}$ & & 10 & $X$ & & & 03 \\
\hline 14 & $\mathrm{X}$ & & 10 & $\mathrm{X}$ & & & 05 \\
\hline 15 & $X$ & & 13 & $X$ & & & 12 \\
\hline
\end{tabular}

O quadro acima evidencia que o júri de especialistas é constituído em sua totalidade por profissionais que possuem curso de pós-graduação na área e $26,66 \%$ possui mestrado. Sua qualificação profissional e participação efetiva no estudo deverão gerar valiosas contribuições ao instrumento ISACS. 


\subsubsection{1a Etapa do Estudo Delphi - Julgamento dos especialistas sobre versão preliminar}

Nessa fase os especialistas foram convidados a participar do estudo Delphi, respondendo a questionário eletrônico sobre a Versão preliminar do ISACS, a opinar sobre ele por meio de escala de opinião de 5 (cinco) pontos, a tecer comentários e sugestões (Tabela 4.2)

Tabela 4.2 - Primeira fase do estudo Delphi, julgamento especialistas - versão preliminar ISACS

\section{Opiniões}

\section{Graus de concordância (№ e \%)}

Referentes à forma e ao conteúdo do Instrumento

1. O Instrumento foi construído de modo que o enfermeiro realize uma supervisão que favoreça práticas mais abertas, participativas e colaborativas.

2. No que corresponde à disposição dos itens o instrumento está adequado.

3. A linguagem adotada no instrumento mostra-se acessível a enfermeiros e ACS.

4. O instrumento contém informações que são pertinentes acerca do trabalho desenvolvido pelo ACS.

5. Os dados referentes á produtividade são relevantes para a supervisão do ACS pelo enfermeiro.

6. Os dados referentes á vigilância em saúde são relevantes para a supervisão do ACS pelo enfermeiro.

7. É pertinente a caracterizacão de uma família em um instrumento de supervisão.

\begin{tabular}{c|c|c|c|c}
\hline CP & C & NN & D & DP \\
\hline 08 & 06 & 01 & 0 & 0 \\
\hline $53,33 \%$ & $40 \%$ & $6,66 \%$ & 0 & 0 \\
\hline 10 & 5 & 0 & 0 & 0 \\
\hline $66,66 \%$ & $33,33 \%$ & 0 & 0 & 0 \\
\hline 10 & 5 & 0 & 0 & 0 \\
\hline $66,66 \%$ & $33,33 \%$ & 0 & 0 & 0 \\
\hline 09 & 05 & 0 & 01 & 0 \\
\hline $60 \%$ & $33,33 \%$ & 0 & $6,66 \%$ & 0 \\
\hline 08 & 07 & 0 & 0 & 0 \\
\hline $53,33 \%$ & $46,66 \%$ & 0 & 0 & 0 \\
\hline 06 & 09 & 0 & 0 & 0 \\
\hline $40 \%$ & $60 \%$ & 0 & 0 & 0 \\
\hline 10 & 5 & 0 & 0 & 0 \\
\hline $66,66 \%$ & $33,33 \%$ & 0 & 0 & 0 \\
\hline 0 & 0 & 0 & 0 \\
\hline 0
\end{tabular}


Graus de concordância (№ e \%)

8. No que se refere a caracterização de uma família o propósito do instrumento é contextualizar a estrutura e a dinâmica familiar sua inserção social e questão de saúde.

\section{A caracterizacão de uma família} visitada deve ser reconstruída periodicamente.

10. A utilização de Genograma e Ecomapa é pertinente para contextualizar a dinâmica familiar e inserção social.

11. Os itens dificuldades encontradas pelos ACS em relação ao trabalho no período e problemas identificados pelo enfermeiro e ACS na visita estão adequados ao propósito do instrumento.

12. Os itens ações propostas pelo enfermeiro e ACS para a redução dos problemas identificados e acompanhados e acompanhamento/avaliacão das ações propostas estão adequado aos propósitos do instrumento.

13. O item acompanhamento e avaliação deve ser revisto periodicamente

14. No que se refere à educacão em saúde a proposta está adequada aos propósitos do instrumento.

15. Esse instrumento mostra-se como um recurso útil na perspectiva de uma supervisão participativa e colaborativa.

\begin{tabular}{l|l|l}
\hline Legenda: & CP: Concordo plenamente & C: Concordo \\
\hline & NN: Nem concordo e nem discordo & D: Discordo \\
\hline & DP: Discordo Plenamente & \\
\hline
\end{tabular}


A versão preliminar do ISACS encaminhada aos especialistas já contempla a sugestão do pré-teste de organizar o instrumento por domínios, sendo esses: Produtividade, Vigilância em Saúde, Caracterização de uma família: ações a serem desenvolvidas, Dificuldades e problemas identificados no território: ações propostas, acompanhamento e avaliação e educação e saúde.

Apesar do alto grau de concordância em relação à compreensão do ISACS, os especialistas tecem comentários e observações que designamos como criticas e sugestões (Quadro 4.5 e 4.6). Essas criticas e sugestões foram organizados seguindo os domínio do ISACS, muitas delas foram incorporados a $1^{\text {a }}$ versão ajustada do ISACS e serão apresentados a seguir.

Quadro 4.5 - Sugestões dos especialistas quanto à versão preliminar do ISACS

\begin{tabular}{|c|c|c|c|c|}
\hline \multirow[b]{2}{*}{ Domínios } & \multirow[b]{2}{*}{ Sugestões } & \multicolumn{2}{|c|}{ Incorporação } & \multirow[b]{2}{*}{ Freq. } \\
\hline & & $\begin{array}{c}\text { Ao } \\
\text { Instrumento }\end{array}$ & $\begin{array}{c}\text { Nas } \\
\text { instruções } \\
\text { para a } \\
\text { aplicação }\end{array}$ & \\
\hline Produtividade & $\begin{array}{l}\text { Criar um campo para registrar os } \\
\text { dias que as ACS não estão em } \\
\text { atividade no território }\end{array}$ & $x$ & & 03 \\
\hline \multirow{4}{*}{$\begin{array}{l}\text { Vigilância em } \\
\text { Saúde }\end{array}$} & $\begin{array}{l}\text { Utilizar referencial teórico para } \\
\text { basear o risco }\end{array}$ & $x$ & & 04 \\
\hline & $\begin{array}{l}\text { Acrescentar dados referentes ao } \\
\text { acompanhamento oncológico }\end{array}$ & $x$ & & 02 \\
\hline & $\begin{array}{l}\text { Acrescentar dados referentes o } \\
\text { número de homens e } \\
\text { adolescentes }\end{array}$ & $x$ & & 02 \\
\hline & $\begin{array}{c}\text { Acrescentar dados referentes à } \\
\text { Arboviroses. }\end{array}$ & & & 01 \\
\hline
\end{tabular}




\begin{tabular}{|c|c|c|c|c|}
\hline \multirow{2}{*}{ Domínios } & \multirow[b]{2}{*}{ Sugestões } & \multicolumn{2}{|c|}{ Incorporação } & \multirow[b]{2}{*}{ Freq. } \\
\hline & & $\begin{array}{c}\text { Ao } \\
\text { Instrumento }\end{array}$ & $\begin{array}{l}\text { Nas instruções } \\
\text { para a } \\
\text { aplicação }\end{array}$ & \\
\hline \multirow{3}{*}{$\begin{array}{l}\text { Caracterização } \\
\text { de uma família } \\
\text { ações a serem } \\
\text { desenvolvidas }\end{array}$} & $\begin{array}{l}\text { Reaplicar a Caracterização de } \\
\text { acordo com a dinâmica familiar. }\end{array}$ & & $X$ & 05 \\
\hline & $\begin{array}{l}\text { Reaplicar a Caracterização de } \\
\text { acordo com os problemas } \\
\text { levantados e os planos de } \\
\text { cuidados estabelecidos }\end{array}$ & & $X$ & 05 \\
\hline & $\begin{array}{l}\text { Realizar a caracterização } \\
\text { principalmente com as famílias } \\
\text { de risco }\end{array}$ & & $\mathrm{X}$ & 01 \\
\hline \multirow{2}{*}{$\begin{array}{c}\text { Dificuldades e } \\
\text { Problemas } \\
\text { identificados } \\
\text { no território: } \\
\text { ações } \\
\text { propostas }\end{array}$} & $\begin{array}{l}\text { Incluir um campo para o ACS } \\
\text { identificar os problemas que } \\
\text { encontra no território }\end{array}$ & $\mathrm{X}$ & & 01 \\
\hline & $\begin{array}{l}\text { Incluir as ações que o ACS } \\
\text { desenvolve no território }\end{array}$ & $\mathrm{X}$ & & 02 \\
\hline \multirow[t]{2}{*}{$\begin{array}{l}\text { Acompanhame } \\
\text { nto e avaliação }\end{array}$} & $\begin{array}{l}\text { Avaliar de acordo com a rotina } \\
\text { de supervisão dos enfermeiros, } \\
\text { ou seja, com prazos flexíveis. }\end{array}$ & & $X$ & 05 \\
\hline & Avaliar mensalmente & & & 02 \\
\hline \multirow{2}{*}{$\begin{array}{c}\text { Educação em } \\
\text { Saúde }\end{array}$} & $\begin{array}{l}\text { Utilizar esse espaço para } \\
\text { qualificar o trabalho do ACS }\end{array}$ & $X$ & $X$ & 01 \\
\hline & $\begin{array}{l}\text { Utilizar espaço para trabalhar } \\
\text { lacunas na formação do ACS }\end{array}$ & $X$ & $X$ & 02 \\
\hline Total & & & & 36 \\
\hline
\end{tabular}

Quadro 4.6 - Críticas dos especialistas quanto a versão preliminar do ISACS

\begin{tabular}{|l|c|}
\hline \multicolumn{1}{|c|}{ Críticas } & Freq. \\
\hline Falta referencial teórico na classificação do Risco & 04 \\
\hline $\begin{array}{l}\text { A utilização do Genograma e Ecomapa demanda muito tempo } \\
\text { para preenchimento }\end{array}$ & 01 \\
\hline $\begin{array}{l}\text { Esclarecer se a proposta de educação em saúde é de } \\
\text { elaboração individual do enfermeiro ou em parceria com o ACS }\end{array}$ & 01 \\
\hline $\begin{array}{l}\text { Não utilizar a palavra acompanhamento no tópico de vigilância } \\
\text { em saúde, para que todos os tópicos sejam utilizados como } \\
\text { indicador }\end{array}$ & 01 \\
\hline Total & 08 \\
\hline
\end{tabular}


Como foi dito anteriormente parte significativa das críticas e sugestões foram incorporadas a 1aㅡ versão ajustada do ISACS independente da frequência em que foram expressas. Os ajustes realizados apoiaram-se em consulta a literatura e visaram aprimorar o Instrumento com vistas a sua aplicação. As principais propostas de modificação estão apresentadas a seguir.

\section{Produtividade}

Apesar de todos os especialistas concordarem com a relevância desses dados para a supervisão do ACS, 3 (20\%) apontam como sugestão criar um campo para registrar os dias que as ACS não estão em atividade no território. Consideramos oportuna essa sugestão, abrimos um campo para registro de dias de "atividades realizadas na USF/ou em outro local" pois por vezes o ACS está desenvolvendo suas atividades laborais, porém em outras locais que não diretamente no território.

\section{Vigilância em Saúde}

Ainda que todos os especialistas concordem que os dados referentes a vigilância em saúde são relevantes para a supervisão do ACS, apresentam sugestões acerca dos dados apresentados e consideram que eles devem ser ampliados, a fim de contemplar outras populações. Essa sugestão mostra-se oportuna tendo em vista que o Instrumento ISACS, em sua versão preliminar aborda apenas algumas populações. Nessa nova perspectiva o olhar para a população está ampliado contemplando as diversas faixas etárias e os principais agravos à saúde.

Dos especialistas, 1 (6.66\%) assentiu como sugestão a inclusão dos dados referentes à Arboviroses, porém por se tratar de um agravo sazonal não foi contemplado no Instrumento que tem uma proposta ampla não se limitando a eventos de um determinado período do ano.

Outro ponto levantado por $4(26,66 \%)$ dos especialistas foi a questão da utilização de um referencial teórico para a classificação do risco familiar, tal sugestão foi acatada em razão da sua relevância, e para tal classificação lançamos mão da Classificação de risco familiar com base na escala de Coelho e Savassi ${ }^{(57)}$ que é uma ferramenta de estratificação da vulnerabilidade familiar, 
que se aproxima das sentinelas de risco avaliados em visita domiciliar pelo ACS e é amplamente conhecida por profissionais da ESF.

Um ponto criticado por $1(6,66 \%)$ dos especialistas é a utilização da palavra "acompanhamento" no domínio vigilância em saúde, tais especialistas sugerem não utilizar essa palavra, para que assim todos os tópicos sejam utilizados como indicador, considerando a relevância da colocação, tal sugestão foi incorporada ao instrumento ISACS.

\section{Caracterização de uma família visitada}

Entre os especialistas, $10(66,66 \%)$ concordam plenamente que a caracterização de uma família em um instrumento de supervisão é pertinente e que o propósito do instrumento ao fazê-lo é contextualizar a estrutura e a dinâmica familiar, sua inserção social e questões de saúde. Para essa caracterização os pesquisadores propõem a utilização de Genograma e Ecomapa, e $12(80,0 \%)$ dos especialistas concordam plenamente com sua utilização, considerando essas ferramentas adequadas para contextualizar a dinâmica familiar e inserção social. Apenas $1(6,66 \%)$ tece crítica com relação à utilização de genograma e ecomapa com a justificativa de que sua aplicação demanda muito tempo para preenchimento.

No que corresponde a reaplicação da caracterização familiar, 8 (53,33\%) acreditam que ela deve ocorrer de forma periódica, para $5(33,33 \%)$ a reavaliação deve ser determinada com base na dinâmica familiar e 5 (33,33\%) consideram que a reavaliação deve ocorrer de acordo com os problemas levantados e os planos de cuidado estabelecidos, essas sugestões foram incorporadas nas "Instruções para a aplicação do instrumento".

Entre os especialistas $1(6,66 \%)$ aponta como sugestão que a caracterização familiar deve ser realizada principalmente com as famílias de risco, tal sugestão foi incorporada às "Instruções para a aplicação do Instrumento".

\section{Dificuldades e problemas identificados no território: ações propostas}

Quando abordamos no instrumento as dificuldades identificadas no território, 07 (46,66\%) especialistas concordam plenamente com a relevância 
do tema para o mesmo, entre os especialistas $1(6.66 \%)$ coloca como sugestão incluir um campo para o ACS identificar os problemas que ele encontra no território e 2 (13,33\%) sugerem incluir ações que o ACS desenvolve no território. Sendo assim consideramos oportunas essas sugestões e abrimos um campo para: Quais os problemas identificados pelo ACS no território e Ações desenvolvidas pelo ACS no território (na comunidade, na família ou com o individuo).

No que se refere às ações propostas, 10 (66.66\%) especialistas concordam plenamente com a sua relevância para o instrumento.

\section{Acompanhamento e Avaliação}

Dos especialistas, $10(66,66 \%)$ concordam plenamente que esse domínio está adequado aos propósitos do instrumento ISACS e 11 (73,33\%) concordam plenamente que informações referentes à esse domínio devem ser revistas periodicamente, entretanto $2(13,33 \%)$ sugerem que a avaliação ocorra mensalmente e $5(33,33 \%)$ sugerem que a avaliação ocorra de acordo com a rotina de supervisão dos enfermeiros com prazos flexíveis. Tal sugestão proposta pela maior parte dos especialistas foi incorporada às "Instruções para aplicação do instrumento".

\section{Educação em Saúde}

No que se refere à educação em saúde 9 (60\%) dos especialistas concordam plenamente que a proposta está de acordo com os propósitos do instrumento, entretanto 1 (6,66\%) especialista sente a necessidade de esclarecimentos se a proposta de educação em saúde é de elaboração do enfermeiro ou em parceria com o ACS, sendo assim complementamos o domínio que passa a ser descrito da seguinte forma no instrumento: Educação em Saúde: Propostas elaboradas pelo enfermeiro e ACS para qualificação do trabalho do ACS.

Entre os especialistas 11 (73,33\%) concordam plenamente que esse instrumento é um recurso útil na perspectiva de uma supervisão participativa e colaborativa.

Salienta-se que os especialistas fizeram sugestões adicionais quanto a aspectos gerais do instrumento e que versaram basicamente sobre forma e 
periodicidade de aplicação do ISACS, levando em consideração a aplicação compartilhada entre Enfermeiro e ACS onde a supervisão possa contemplar todas as situações previstas no ISACS numa única supervisão ou realizarem uma supervisão por domínio, a depender da experiência dos participantes. Assim, ainda que não tenham sugerido inclusão tampouco tenham criticado ausência, considerou-se pertinente elaborar ORIENTAÇÕES PARA APLICAÇÃO DO ISACS (Apêndice D) e que reunissem estas sugestões. Essas orientações foram submetidas a julgamento na $2^{\text {a }}$ fase do estudo Delphi juntamente com os domínios do ISACS. 


\subsection{1 $2^{\text {a }}$ fase do estudo Delphi}

Nessa fase os especialistas foram convidados a opinar (Tabela 4.3), por meio de questionário eletrônico, sobre a $1^{\text {a }}$ versão ajustada do Instrumento quanto ao conteúdo e linguagem de:

- Cada domínio do instrumento e

- Orientações para aplicação do ISACS

O nível de consenso estabelecido para a confirmação dos domínios do instrumento é de $80 \%$, para conteúdo e linguagem, os itens do instrumento que forem aprovados em seu conteúdo e linguagem por $80 \%$ ou mais especialistas serão mantidos; Itens reprovados em seu conteúdo por mais de $20 \%$ dos juízes serão excluídos e itens reprovados por mais de $20 \%$ quanto à linguagem serão modificados e serão submetidos a julgamento, de modo a gerar a $2^{\underline{a}}$ versão ajustada do instrumento.

Tabela 4.3 - Julgamento dos Especialistas sobre a $1^{\text {a }}$ versão Ajustada do ISACS

\begin{tabular}{|c|c|c|c|c|}
\hline \multirow{3}{*}{$\begin{array}{l}\text { QUESTÕES } \\
\text { POR DOMIINIO }\end{array}$} & \multicolumn{4}{|c|}{ ESPECIALISTAS } \\
\hline & \multicolumn{2}{|c|}{ LINGUAGEM } & \multicolumn{2}{|c|}{ CONTEÚDO } \\
\hline & Aprova & Não Aprova & Aprova & Não Aprova \\
\hline \multirow{2}{*}{ 1. Produtividade } & 15 & 0 & 15 & 0 \\
\hline & $100 \%$ & & $100 \%$ & \\
\hline \multirow{3}{*}{ 2. Vigilância em Saúde } & 15 & 0 & 11 & 1 \\
\hline & & & & 1 \\
\hline & $100 \%$ & & $93,33 \%$ & $5,55 \%$ \\
\hline \multirow{2}{*}{$\begin{array}{l}\text { 3. Caracterização de uma } \\
\text { família visitada: ações a serem } \\
\text { desenvolvias }\end{array}$} & 15 & 0 & 15 & 0 \\
\hline & $100 \%$ & & $100 \%$ & \\
\hline \multirow[t]{2}{*}{$\begin{array}{l}\text { 4. Dificuldades e problemas } \\
\text { identificados }\end{array}$} & 15 & 0 & 14 & 1 \\
\hline & $100 \%$ & & $93,33 \%$ & $6,66 \%$ \\
\hline \multirow{2}{*}{$\begin{array}{l}\text { 5. Ações a serem } \\
\text { desenvolvidas pelo ACS na } \\
\text { comunidade, na família ou com } \\
\text { o individuo. }\end{array}$} & 15 & 0 & 15 & 0 \\
\hline & $100 \%$ & & $100 \%$ & \\
\hline
\end{tabular}


QUESTÕES

POR DOMÍNIO

\section{ESPECIALISTAS}

\begin{tabular}{|c|c|c|c|}
\hline \multicolumn{2}{|c|}{ LINGUAGEM } & \multicolumn{2}{c|}{ CONTEÚDO } \\
\hline Aprova & Não Aprova & Aprova & Não Aprova \\
\hline
\end{tabular}

blemas identificados pela enfermeira na supervisão

\begin{tabular}{|c|c|c|c}
\hline 15 & 0 & 15 & 0 \\
\hline $100 \%$ & & $100 \%$ & \\
\hline
\end{tabular}

7. Ações Propostas pelo enfermeiro e ACS para redução dos problemas identificados

\begin{tabular}{|c|c|c|c|}
\hline 14 & 1 & 14 & 1 \\
\hline $93,33 \%$ & $6,66 \%$ & $93,33 \%$ & $6,66 \%$ \\
\hline
\end{tabular}

8. Acompanhamento e Avaliação das ações.

\begin{tabular}{|c|c|c|c|}
\hline 14 & 1 & 14 & 1 \\
\hline $93,33 \%$ & $6,66 \%$ & $93,33 \%$ & $6,66 \%$ \\
\hline
\end{tabular}

9. Educação em saúde

\begin{tabular}{|c|c|c|c|}
\hline 15 & 0 & 15 & 0 \\
\hline $100 \%$ & & $100 \%$ & \\
\hline
\end{tabular}

10. Orientações para aplicação do instrumento

15

$100 \%$

0

\begin{tabular}{|c|c|c}
\hline 15 & 0 \\
\hline $100 \%$ & \\
\hline
\end{tabular}

Quanto ao conteúdo a $1^{\text {a }}$ versão ajustada do ISACS obteve aprovação do conjunto de especialistas para a totalidade dos itens que o compõe, variando de $93,33 \%$ a $100 \%$.

Quanto a linguagem a $1^{\text {a }}$ versão ajustada do ISACS obteve aprovação do conjunto de especialistas para a totalidade dos itens mantendo a mesma variação observada no julgamento do conteúdo.

Apesar do alto grau de concordância, os especialistas tecem comentários em relação ao conteúdo e linguagem (Quadro 4.7): 
Quadro 4.7- Comentários dos Especialistas quanto à 1aㅡ versão ajustada do ISACS

\begin{tabular}{|l|c|}
\hline \multicolumn{1}{|c|}{ Comentários } & Freq. \\
\hline $\begin{array}{l}\text { Quanto ao conteúdo da questão de vigilância em saúde incluiria } \\
\text { dados que pudessem ser utilizados nos indicadores pactuados. } \\
\text { Utilizando como base o PMAQ e outros do Ministério da Saúde. }\end{array}$ & 01 \\
\hline $\begin{array}{l}\text { Quanto ao conteúdo das questões “dificuldades e problemas } \\
\text { identificados pelo ACS na visita domiciliar" e "dificuldades e } \\
\text { problemas identificados pelo ACS na visita no território" ambas } \\
\text { parecem dizer a mesma coisa, não ficou claro se é de uma } \\
\text { família específica ou se é de todo o território. }\end{array}$ & 01 \\
\hline $\begin{array}{l}\text { Quanto ao conteúdo e linguagem da questão ações propostas } \\
\text { pelo enfermeiro e ACS para a redução dos problemas } \\
\text { identificados mudaria para pactuações estabelecidas entre } \\
\text { enfermeiro e ACS a partir de fragilidades identificadas. }\end{array}$ & 01 \\
\hline $\begin{array}{l}\text { Quanto ao conteúdo e linguagem da questão de } \\
\text { acompanhamento e avaliação das ações tiraria propostas pelo } \\
\text { enfermeiro e colocaria pactuadas entre enfermeiro e ACS }\end{array}$ & 01 \\
\hline Total & 04 \\
\hline
\end{tabular}

Considerando o comentário referente ao conteúdo adotada no domínio Vigilância em Saúde que sugere a inclusão de dados que pudessem ser utilizados nos indicadores pactuados pelo Ministério da Saúde. Os dados coletados com o ISAC tem como base o Sistema de Informação da Atenção Básica do Ministério da Saúde.

No que se refere à semelhança entre os enunciados das questões "dificuldades e problemas identificados pelo ACS na visita domiciliar" e "dificuldades e problemas identificados pelo ACS na visita no território" salientase que a primeira questão refere-se às principais dificuldades verificadas pelo ACS na visita domiciliar. Essa questão no ISACS inclui exemplos como: dificuldades de vinculação com a população, dificuldade quanto à adesão do tratamento, sendo esses dados voltados ao individuo e/ou núcleo família. A 
segunda se refere às dificuldades encontradas no território em que as várias famílias sob o seu acompanhamento estão inseridas. Por se tratar de uma colocação pontual, optamos por realizar mudanças nessas questões.

Quando o especialista sugere a mudança da palavra "propostas" para "pactuações", compreendemos que ambas atendem o propósito do instrumento sem mudar o real sentido do mesmo se trocadas, sendo assim mantemos a palavra proposta no enunciado das questões.

Tendo em vista o alto índice de concordância entre os especialistas e que não houve modificações no Instrumento (Apêndice H) após análise dos comentários, não foi necessária a condução da $3^{\underline{a}}$ etapa do estudo Delphi que se destinaria ao julgamento dos itens modificados na $2^{\mathrm{a}}$ etapa. Obtendo assim já na segunda etapa a versão consensuada do instrumento. 


\section{$5 \quad$ DISCUSSÃO}

O Júri de especialistas dessa pesquisa, é constituído em sua totalidade por profissionais que possuem curso de pós-graduação. Segundo Silva et $\mathrm{al}^{(31)}$ a grande prevalência de profissionais que cursaram ou estão cursando uma pós-graduação demonstra uma tendência de busca de melhor qualificação por meio de cursos de especialização na área da saúde. Ademais, o Ministério da Saúde tem adotado a estratégia de favorecer a qualificação profissional no sentido de fortalecer as políticas no setor público de saúde.

O Programa Saúde da Família hoje exige a qualificação de uma grande quantidade de profissionais, tendo em vista as necessidades de expansão desta estratégia afim de consolidá-la em todo o território nacional. Assim sendo é necessário que o enfermeiro de saúde da família tenha uma formação essencialmente voltada para a realidade de saúde da população, ou seja, isto implica relacionar-se com toda a complexidade de nossa malha social, econômica e cultural e a partir deste processo melhorar as condições de saúde desta população ${ }^{(46)}$.

Quando empregamos a Técnica Delphi, a formação profissional do Juri de especialistas é imprescindível, pois confere validade externa aos resultados $^{(40)}$.

\subsection{DISCUSSÃO 1a FASE DO ESTUDO DELPHI}

Quando abordamos o Domínio Produtividade os especialistas sugeriram criar um campo para registrar os dias que as ACS não estão em atividade no território.

Nascimento ${ }^{(58)}$, identifica que há uma gama de atividades desenvolvidas pelo ACS que combinam com o objetivo da incorporação desse profissional às equipes de referência: visita domiciliar, participação em grupos educativos (hipertensos, diabéticos, gestantes, recém-nascidos etc.), vigilância à dengue, cadastro de renda mínima, busca ativa de faltosos, trabalho 
comunitário, cadastramento, dentre outros. Por outro lado, desempenham também atividades administrativas não relacionadas ao seu núcleo de conhecimento, sendo estas funções efetivadas por deficiência de recursos humanos.

Em consonância com a opinião dos especialistas e de Nascimento ${ }^{(58)}$, admitiu-se a relevância da criação do campo para registro dos dias no ISACS.

No Domínio Vigilância em Saúde os especialistas colaboraram com variadas sugestões, a primeira delas foi a de ampliar as populações contempladas no domínio.

Tendo em vista que a supervisão contribui para a qualificação da assistência prestada ao usuário e que tal qualificação está principalmente voltada para a vigilância em saúde com ações programáticas e prevenção de agravos por meio da passagem de informações ${ }^{(45)}$, a ampliação das populações contempladas é fundamental para o conhecimento do território e planejamento de ações de saúde.

Outra sugestão foi à inclusão dos dados referentes à arboviroses, entretanto é necessário considerar que em algumas regiões do país as arboviroses apresentam caráter sazonal, sendo a estação de maior risco o verão, momento em que as ações preventivas tendem a ser intensificadas ${ }^{(59)}$. Assim sendo a inclusão destes dados não corresponde a proposta do ISACS que é ampla e portanto não se limita a eventos de um determinado período do ano.

Os especialistas também sugeriram a utilização de um referencial teórico para a classificação do risco familiar, e para tal escolhemos uma escala amplamente utilizada pelas equipes de saúde da família, a Escala de Risco Familiar de Coelho-Savassi. Essa escala consiste em uma ferramenta de estratificação de risco familiar, aplicada às famílias adscritas a uma equipe de saúde, por meio da qual busca-se determinar seu risco social e de saúde, o que reflete o potencial de adoecimento de cada núcleo familiar. Para o preenchimento da escala utiliza-se de dados colhidos em visita domiciliar pelo ACS, disponíveis na rotina das equipes de saúde da família ${ }^{(57)}$.

Dessa forma reconhecemos a importância da utilização de um referencial teórico para a classificação de risco, e o quanto essa sugestão enriquece o ISACS. 
Um ponto criticado pelos especialistas é a utilização da palavra "acompanhamento" no domínio vigilância em saúde, os mesmos sugerem não utilizar essa palavra, para que assim todos os tópicos sejam utilizados como indicadores.

Para Cassiolato ${ }^{(60)}$ o indicador possibilita captar as informações averiguar sentido e intensidade de uma variável ou conjunto de variáveis relevantes para o enfrentamento do problema.

Desta maneira quando retiramos do domínio a palavra "acompanhamento", damos a ele características de indicador, ampliamos o alcance das informações a serem obtidas com o ISACS.

Os especialistas concordam que o ISACS deva contemplar o domínio Caracterização de uma família visitada, sendo esse pertinente ao propósito do Instrumento, por meio dessa caracterização contextualiza-se a estrutura e a dinâmica familiar, sua inserção social e questões de saúde. Segundo Schwartz ${ }^{(61)}$ a família é um sistema dinâmico, que se inter-relaciona com outros sistemas, modifica-se com o passar do tempo e ocupa papéis em vários sistemas sociais, dando sustento e cuidado aos indivíduos que o integram, por isso pode constituir-se como um elemento de apoio a eles.

Para tal caracterização propomos a utilização de Genograma e Ecomapa, como ferramentas para contextualizar a dinâmica familiar e inserção social. Porém um especialista apontou como crítica que a aplicação da ferramenta demanda de muito tempo para preenchimento.

No entanto o Bousso ${ }^{(62)}$ considera que o genograma e o ecomapa são instrumentos que facilitam a avaliação da estrutura familiar. Através deles é possível ter uma rápida visão da complexidade das relações familiares e são ricas fontes de informação, de forma sucinta, para o planejamento de estratégias.

Assim sendo a utilização de tais ferramentas no ISACS, é importantíssima para ampliar o conhecimento sobre as famílias do território bem como planejar ações de saúde voltadas as especificidades de cada uma.

A reaplicação da caracterização familiar, para os especialistas deve ocorrer de forma periódica e de acordo com os problemas levantados e os planos de cuidado estabelecidos. 
De acordo com Reis e Hortale ${ }^{(9)}$ as ações devem ser avaliadas da forma contínua, revendo sempre o planejamento inicial e replanejando de acordo com a necessidade, devendo estar voltada para a caracterização dos resultados obtidos, adequação das propostas e sua praticidade.

Outro ponto levantado pelos especialistas, é que a caracterização familiar deve ser realizada principalmente com as famílias de risco, Segundo Abrahão ${ }^{(63)}$ a programação da abordagem familiar em saúde deve ocorrer através da análise da situação de saúde, por meio dos padrões de adoecimento, vulnerabilidade e risco.

No domínio Dificuldades e problemas identificados no território: ações propostas os especialistas entendem como relevante o tema para ISACS. Em concordância com os especialistas Rabelo, ${ }^{(49)}$ e Bôas, et AL (50) expõem que se as equipes, a partir do entendimento de dificuldades e limitações, tiverem a oportunidade de trabalhar estas questões, este quadro poderá se reverter; mas para que isto aconteça é necessário que a supervisão seja capaz de dar suporte às equipes, proporcionamos encontros, momentos de troca de saberes e práticas, de acolhimento, e, essencialmente, momentos de construção coletiva, visando romper com o que está dado.

Buscando aperfeiçoar esse Domínio, os especialistas sugerem a criação de dois novos campos, sendo o primeiro referentes aos problemas identificados pelo ACS no território e o segundo as ações desenvolvidas pelo ACS no território (na comunidade, na família ou com o individuo), acreditamos que ambas as sugestões contribuem com o ISACS. Segundo Costa et $a^{(64)} 0$ trabalho do ACS, na Atenção Básica, é de fundamental importância para a concretização da ESF e efetivação do conceito ampliado de saúde, pois realiza atividades diferenciadas junto à comunidade é considerado um elemento nuclear das ações em saúde, com atividades de prevenção e de vigilância à saúde, por meio das visitas em domicílios e educação em saúde, individual e coletiva.

Quando abordamos o domínio Acompanhamento e Avaliação os especialistas entendem que o mesmo deverá ser revisto periodicamente, levando em consideração a rotina de supervisão dos enfermeiros com prazos flexíveis, substanciando os Especialistas Gama ${ }^{(52)}$ aponta que avaliação da supervisão deve ser realizada pelo enfermeiro de forma contínua, revendo 
sempre o planejamento inicial e replanejando de acordo com a necessidade, uma vez que é um meio e não um fim em si mesma, devendo estar voltada para a caracterização dos resultados obtidos, adequação das propostas e sua praticidade.

O último domínio do ISACS aborda Educação em Saúde, tal domínio foi amplamente aceito pelos especialistas, que compreendem a sua relevância à proposta do Instrumento. E com o intuito de qualificar esse domínio e reafirmar o propósito de uma supervisão horizontal os especialistas sugerem que mudança no enunciado do Domínio que passa a ser descrito da seguinte forma: Educação em Saúde: Propostas elaboradas pelo enfermeiro e ACS para qualificação do trabalho do ACS

É evidente a necessidade de mudança dos modelos de atenção e supervisão vigentes, em direção a um trabalho construído coletivamente, onde a qualificação possibilite a apropriação de outros saberes e conhecimentos que ofereçam subsídios necessários na complexidade da atenção aos usuários. $O$ êxito desta mudança encontra-se na implementação de ações de educação que fomentem supervisão em uma abordagem mais participativa $e$ colaborativa, com vistas à educação e não punição ${ }^{(9,65,66)}$.

Os especialistas concordam plenamente que ISACS é um recurso proficiente na perspectiva de uma supervisão participativa e colaborativa.

Essa perspectiva é fundamentada por Reis ${ }^{(16)}$ que expõe que a supervisão deve ser exercida através de reflexão, análise de "situaçõesproblemas", troca de experiências, numa perspectiva de cooperação, parceria e participação.

\subsection{DISCUSSÃO 2ª FASE DO ESTUDO DELPHI}

Nessa fase os especialistas foram convidados a opinar sobre a $1^{\text {a }}$ versão ajustada do ISACS quanto ao conteúdo e linguagem de cada domínio. Ambos os quesitos obtiveram aprovação do conjunto de especialistas para a totalidade dos itens que os compõe. 
Apesar do alto grau de concordância, os especialistas teceram comentários, o primeiro deles se refere ao conteúdo da questão de vigilância em saúde, incluir dados que possam ser utilizados nos indicadores pactuados pelo Ministério da Saúde. Os dados de vigilância em saúde coletados através do ISACS tem como base o Sistema de Informação da Atenção Básica (SIAB) implantado em 1998 pelo Departamento de Informática do SUS que foi substituído em 2013 pelo e-SUS da Atenção Básica. Esse sistema tem como objetivo acompanhar as ações e os resultados das atividades realizadas pelo Programa Saúde da Família ${ }^{(34,67)}$.

Outro comentário foi referente ao conteúdo das questões dificuldades e problemas identificados pelo ACS na visita domiciliar e no território, os especialistas apontam a semelhança entre ambas. No entanto no que se refere a semelhança entre as questões no enunciado a primeira questão está se referindo as principais dificuldades verificadas pelo ACS na visita domiciliar voltadas ao individuo e/ou núcleo família, já a segunda se refere as dificuldades encontradas no território em que as várias famílias sob o seu acompanhamento estão inseridas.

Nascimento ${ }^{(68)}$ relata que na prática da visita domiciliar, ao chegar às residências, o ACS enfrenta a problemática de não ser recebido pelas famílias, dificuldades de encontrar o usuário em sua residência, portões fechados, sobretudo moradores que relatam não quererem ser incomodados pelos ACS. Já Brand ${ }^{(69)}$, aborda as dificuldades que o ACS vivencia quanto ao relacionamento interpessoal, dificuldades essas que em muitos casos, interferem na construção do vínculo tão necessário entre o agente e o usuário atendido, o que acaba por criar mais uma barreira entre a unidade de saúde e a família assistida.

Para Almeida et al $^{(70)}$ são muitos os fatores que influenciam a performance das equipes de saúde no território, a esse respeito, sobressai às dificuldades que os ACS possuem em acessá-lo, com imposições e restrições que permeiam o percurso do trabalho diariamente. As implicações mais comuns nesse contexto estão atreladas à noção de violência urbana, com a presença de grupos, facções e pessoas envolvidos em atividades ilícitas, sobretudo com o tráfico de drogas, e a presença arbitrária da polícia. 
Diante do exposto fica clara a diferença entre ambas as questões, sendo assim, optamos por não realizar mudanças.

Os especialistas também comentaram sobre a troca da palavra "proposta" por "pactuação", no dicionário "proposta" é definida como: sugestão; aquilo que se propõe e "pactuação" é definido como fazer um acordo, ajustar $^{(71)}$. Compreendemos que ambas atendem o propósito do instrumento sem mudar o real sentido do mesmo, tendo em vista seus significados semelhantes. 



\section{CONSIDERAÇÕES FINAIS}

A supervisão do trabalho e do trabalhador voltadas ao cumprimento de ordens e de regulamentos, à garantia da produtividade e ao aumento dos lucros atende aos propósitos dos modelos tradicionais de gestão. Dentro desses modelos a supervisão tinha um caráter fiscalizador e punitivo. Atualmente observa-se crescente uso da supervisão como estratégia educativa e motivacional.

Apesar da tendência à mudanças na concepção e uso de supervisão, na área de enfermagem, ainda se identificam dificuldades para compreensão da supervisão como dispositivo que serve a processos educativos e emancipatórios, ou seja, ainda é possível observar nesta área-a influência dos modelos tradicionais de gestão, quando, por exemplo, o enfermeiro faz uso do poder hierárquico para fiscalizar e controlar o trabalho do ACS.

Essa visão de supervisão precisa ser repensada, para dar lugar a novas formas de se organizar o trabalho tendo em vista a estimulação e a potencialização do trabalho do ACS.

Nessa perspectiva foi elaborado e validado, através de revisão bibliográfica e estudo Delphi em 2 etapas, um Instrumento norteador de Supervisão do trabalho do ACS - ISACS, pelo enfermeiro baseado em uma prática administrativa mais aberta, flexível, participativa e colaborativa.

Os especialistas na $1^{\underline{a}}$ etapa opinaram sobre a forma e o conteúdo do instrumento, nessa etapa a média de aprovação do Instrumento foi de 96,85\%, na $2^{a}$ etapa os especialistas opinaram sobre a $1^{\underline{a}}$ versão ajustada do instrumento quanto a conteúdo e linguagem, a aprovação do conteúdo foi de $97,33 \%$ e quanto a linguagem foi de $98,66 \%$.

O ISACS está estruturado por domínios sendo esses: "Produtividade e Vigilância em Saúde", "Caracterização de uma família visitada", "Dificuldade e problemas identificados e ações", "Acompanhamento e Avaliação"e "Educação em Saúde". Os domínios do ISACS têm como propósito abranger o trabalho do ACS no território e facilitar sua aplicação.

A elaboração e validação do ISACS gerou um produto que busca superar a tradicional visão sobre a supervisão e conceitos, que apoiados em 
raízes históricas, a concebiam como instrumento de poder e expressão de autoridade, dando lugar à supervisão compartilhada e consciente, onde juntos, enfermeiros e ACS, constroem o conhecimento, partilham dúvidas e buscam resoluções de problemas.

Optou-se nesse estudo por validar o ISACS a partir do julgamento do mesmo por enfermeiros com experiência na ESF, o que qualificou 0 Instrumento elaborado por meio de revisão bibliográfica, quanto à abrangência de itens, forma e periodicidade de aplicação.

Novos estudos poderão ser conduzidos após um período de experimentação do ISACS reunindo opiniões, comentários e sugestões dos especialistas e ACS sobre possibilidades e limites do Instrumento, visando seu aprimoramento. 


\section{REFERÊNCIAS ${ }^{1}$}

1. Saúde Md. Política Nacional de Atenção Básica. normas e manuais técnicos. Série Pactos pela Saúde; 2017.

2. Chiavenato I. Administração nos novos tempos. Rio de Janeiro: Elsevier Brasil; 2005.

3. Laranjeira, SMG. Fordismo e Pós-fordismo. Trabalho e Tecnologia: dicionário crítico. Petrópolis: Vozes; Porto Alegre: Editora da UFRGS, 1997.

4. Matos E, Pires D. Teorias administrativas e organização do trabalho: de Taylor aos dias atuais, influências no setor saúde e na enfermagem. Texto \& Contexto Enfermagem. [Internet], 2006. [citado 13 ago 2017]. Disponível em: http://www.scielo.br/pdf/tce/v15n3/v15n3a17.

5. Chiavenato I. Introdução à teoria geral da administração. Rio de Janeiro: Elsevier Brasil, 2003.

6. Servo MLS. O pensar, o sentir, e o agir da enfermeira no exercício da supervisäo na rede SUS local: o (re) velado de uma práxis [tese]. São Paulo.Universidade de São Paulo, Escola de Enfermagem, 1999.

7. Silva, ABF. A supervisão do agente comunitário de saúde: limites e desafios para a enfermeira [dissertação]. Escola Nacional de Saúde Pública Sergio Arouca, Fundação Oswaldo Cruz; 2002.

8.Alarcão I, Canha B. Supervisão e colaboração: uma relação para o desenvolvimento. Porto: Porto Editora, 2013.

9. Reis CCL, Hortale VA. Programa Saúde da Família: supervisão ou convisão? Estudo de caso em município de médio porte. Cadernos de Saúde Pública 20, 2004.

10. Moreira MA. Narrativas dialogadas na investigação, formação e supervisão de professores. Mangualde: Pedago, 2011.

\footnotetext{
${ }^{1}$ De acordo com Estilo Vancouver.
} 
11. Nunes TCM. A supervisão: uma proposta pedagógica para o setor saúde. Cad Saúde Pública. 1986; 2: 466-76.

12. Leopardi, MT et al. O processo de trabalho em saúde: organização e subjetividade. Florianópolis: Papa-Livros, 1999.

13. Carvalho JFS, Chaves LDP. Supervisão de enfermagem no contexto hospitalar: uma revisão integrativa. Revista Eletrônica de Enfermagem; 13(3):546-553. [Internet] 2011. [citado 13 ago 2017]. Disponível em: https://www.fen.ufg.br/revista/v13/n3/pdf/v13n3a21.pdf.

14. Santiago ARJV, Cunha JXP. Supervisão de enfermagem: instrumento para a promoção da qualidade na assistência. Saúde Pesquisa; 2011; 4 (3).p. 444448.

15. Costa MML, Fontoura MS. A supervisão como estratégia de acompanhamento e avaliação das práticas das equipes de saúde da família.

Cogitare Enfermagem 17.4; [Internet] 2012. [citado 13 ago 2017]. Disponível em: https://revistas.ufpr.br/cogitare/article/view/30386.

16. Reis CCL, et al. Supervisão no programa de saúde da família: limites e possibilidades [tese] [internet]; Rio de Janeiro 2001. [citado 12 set 2017]. Disponível em: http://teses.icict.fiocruz.br/pdf/reiscclm.pdf.

17. Paim JS. Modelos de atenção à saúde no Brasil. Giovanela L, Escorel S, Lobato LVC, Noronha JC, Carvalho AI, organizadores. Políticas e sistemas de Saúde no Brasil. Rio de Janeiro: Fiocruz;; 2008. p.88-115.

18. Saúde Md. 8 ${ }^{a}$ Conferência Nacional de Saúde: relatório final. Brasília: Ministério da Saúde; [Internet] 1986. [citado 11 set 2017]. Disponível em: http://www.conselho.saude.gov.br/biblioteca/Relatorios/relatorio_8.pdf

19. Brasil. Lei n. 8.080 de 19 dde setembro de 1990. Dispõe sobre as condições para a promoção, proteção e recuperação da saúde, a organização e o funcionamento dos serviços correspondentes e dá outras providências. Diário Oficial da União, Brasília, [Internet] 1990. [citado 11 set 2017]. Disponível em: http://www.planalto.gov.br/ccivil_03/leis//8080.htm. 
20. Brasil. Lei n. 8.142 de 28 de dezembro de 1990. Dispõe sobre a participação da comunidade na gestão do Sistema Único de Saúde (SUS) e sobre as transferências intergovernamentais de recursos financeiros na área da saúde e dá outras providências. Diário Oficial da União, Brasília, [Internet] 1990. [citado 11 set 2017]. Disponível em: http://www.planalto.gov.br/ccivil_03/leis/L8142.htm.

21. Rosa WAG, Labate RC. Programa Saúde da Família: a construção de um novo modelo de assistência. Revista latino-americana de Enfermagem. 13.6: 1027-1034. [Internet]. 2005. [citado 11 set 2017]. Disponível em: redalyc.org/pdf/2814/281421850016.pdf.

22. Sousa MF. A enfermagem reconstruindo sua prática: mais que uma conquista no PSF. Revista Brasileira de Enfermagem;53(SPE):25-30. [Internet] 2000. [citado 11 set 2017]. Disponível em: http://www.scielo.br/scielo.php?pid=S003471672000000700004\&script=sci_arttext.

23. Dalpiaz AK, Stedile NLR. Estratégia Saúde da Família: reflexão sobre algumas de suas premissas. V Jornada Internacional de Políticas PúblicasEstado, Desenvolvimento e Crise do Capital São Luís-MA. 2011.

24. Saúde M. Equipe de Saúde da Família. [homepage]. Divisão da Atenção Primária. [citado 11 set 2017]. Disponível em: http://dab.saude.gov.br/portaldab/smp_como_funciona.php?conteudo=esf.

25. Brasil. Ministério do Estado da Saúde. Portaria o 2.488, de 21 de outubro de 2011. Aprova a Política Nacional de Atenção Básica, estabelecendo a revisão de diretrizes e normas para a organização da Atenção Básica, para a Estratégia Saúde da Família (ESF) eo Programa de Agentes Comunitários de Saúde (PACS). Diário Oficial da República Federativa do Brasil; 2011.

26. Rodrigues WW, Torres VR. Contribuição ao desenvolvimento do processo de supervisão: Centro de Documentação do Ministério da Saúde; 1980.

27. Freire P. Pedagogia do Oprimido. 17ª . Ed Rio de Janeiro: Paz e Terra. 1987.

28. Oliveira VC. Comunicação, informação e participação popular nos conselhos de saúde. Saúde Sociedade. 2004;13(2):56-69. 
29. Silva MJ, Rodrigues RM. O agente comunitário de saúde no processo de municipalização da saúde. Revista Eletrônica de Enfermagem; 2(1).[Internet]; 2000. [citado 12 set 2017]. Disponível em: https://www.revistas.ufg.br/fen/article/view/678.

30. São Paulo. Conselho Regional de Enfermagem. Realização de treinamentos, palestras, cursos e aulas por profissionais de enfermagem. Parecer COREN-SP 028/2014 - CT. Relatora: Gizelda Monteiro da Silva. Câmara Técnica de Educação. São Paulo, 07 jul. 2014. [Internet]. [citado 12 set 2017]. Disponível em: http://ouvidoria.cofen.gov.br/corensp/transparencia/19103/download/PDF.

31. Silva JS. O processo de trabalho do enfermeiro na supervisão ao agente comunitário de saúde em equipes de Saúde da Família [Dissertação]. São Paulo: Universidade de São Paulo, Escola de Enfermagem; 2014.

32. Lima CRA, Schramm JMA, Coeli CM, Silva MEM. Revisão das dimensões de qualidade dos dados e métodos aplicados na avaliação dos sistemas de informação em saúde. Avaliação dos sistemas de informação em saúde. 2009; 25:2095-2109.

33. Saúde M. Manual do Sistema com Coleta de Dados Simplificada - CDS, versão preliminar; Brasília - DF, [Internet] 2014. [citado 12 set 2017]. Disponível em: http://189.28.128.100/dab/docs/portaldab/documentos/manual_CDS_ESUS_1_ 3_0.pdf.

34. Brasília. Conselho Nacional de Secretarios da Saúde - CONASS. Estratégia E-SUS Atenção Básica e Sistemas de Informação em Saúde da Atenção Básica - SISAB. Nota técnica, Brasília - DF. p. 24. [Internet] 2013. [citado 12 set 2017]. Disponível em: https://www.conass.org.br/biblioteca/wpcontent/uploads/2013/01/NT-07-2013-e-SUS-e-SISAB.pdf.

35. Williams PL, Webb C. The Delphi technique: a methodological discussion. J Advanced Nursing. 1994; 19: 180-6

36. Spínola AWP. Delphos: proposta tecnológica alternativa. Edição preliminar São Paulo: Faculdade de Saúde Pública da USP; 1984.

37. Silva RF, Tanaka OY. Técnica Delphi: identificando as competências gerais do médico e do enfermeiro que atuam em atenção primária de saúde. Revista Escola Enfermagem USP. 1999; 33(3): 2017-16. 
38. Faro ACM. Técnica Delphi na validação das intervenções de enfermagem. Rev Escola de Enfermagem da USP. 1997; 31:259-73.

39. Vasconcellos KMAV, Almeida MHM. Percepção de egressos sobre estágios de terapia ocupacional em geriatria e gerontologia. Rev Terapia Ocupacional Universidade de São Paulo. 2013; 24(1):48-56.

40. Spínola AWP. Técnica prospectiva Delphi; [Apostila do Curso de mestrado interinstitucional. FSP-USP - FAESA, 2002.

41. Almeida MHM, Spínola AWP, Lancman S. Técnica Delphi: validação de um instrumento para uso do terapeuta ocupacional em gerontologia. Rev Terapia Ocupacional da Universidade de São Paulo. 2009; 20:49-58.

42. Pasquali L. Princípios de elaboração de escalas psicológicas. Revista Psiquiatria Clinica, São Paulo. 1998; 25 (5): 206-213.

43. Brasil. Instituto Brasileiro de Geografia e Estatistica-IBGE. [homepage] Estimativa 2017 Municipios. [citado 29 jan 2018]. Disponível em: https://agenciadenoticias.ibge.gov.br/agencia-sala-de-imprensa/2013-agenciade-noticias/releases/16131-ibge-divulga-as-estimativas-populacionais-dosmunicipios-para-2017.

44. Lopes R. Desafios para a implantação da Estratégia de Saúde da Família (ESF) em municípios de grande porte: estudo de caso do município de Sorocaba-SP. 2017.

45. Silva JS, Fortuna CM, Pereira MJB, Matumoto S, Santana FR, Marciano FM, Silva, et al. Supervisão dos Agentes Comunitários de Saúde na Estratégia Saúde da Família: a ótica dos enfermeiros. Revista da Escola de Enfermagem da USP, 48.5: 899-906, 2014.

46. Santos MN, Lima ETD, Pinto RNM, Andrade LDFD. Supervisão em Enfermagem: Instrumento administrativo para o trabalho da equipe de saúde. In: 15 CBCENF, 2012, Fortaleza. Anais - 15ํㅡㄹ CBCENF, 2012.

47. Silva CR, Ramos C S, Ceolin RMHT, Dilélio AS, Facchini LA. Perfil do enfermeiro atuante na estratégia saúde da família. Ciência Cuidado Saúde. 2009; 8:85-91. 
48. Machado RR, Júnior EBC, Justi J. O Genograma e o Ecomapa como instrumentos para compreender a rede familiar de uma pessoa com transtorno mental: Um estudo de caso.Revista Interdisciplinar de Estudos em Saúde; 4(2):154-68 [Internet]. 2016. [citado 23 mar 2019] Disponível: http://periodicos.uniarp.edu.br/ries/article/view/725.

49. Rebello TS. Supervisão em enfermagem como processo educativo: limites e possibilidades. [dissertação] [Internet]. Santa Catarina: Universidade Federal de Santa Catarina, 2002. [citado 13 ago 2017]. Disponível em: https://repositorio.ufsc.br/xmlui/bitstream/handle/123456789/82624/187944.pdf? sequence $=1$ \&is Allowed $=\mathrm{y}$.

50. Bôas $V$, et al. A prática gerencial do enfermeiro no PSF na perspectiva da sua ação pedagógica educativa: uma breve reflexão. Ciência Saúde Coletiva. 2008; 13:1355-60.

51. Costa MAO. A supervisão do enfermeiro no trabalho do agente comunitário de saúde: uma revisão bibliográfica. [Monografia]. Belo Horizonte: Universidade Federal de Minas Gerais, 2011.

52. Gama BMBM. Supervisão em enfermagem: compreender a supervisão como um instrumento de orientação da equipe de enfermagem para uma prática de qualidade. [homepage]. Juiz de Fora-MG. [citado 21 mai 2019]. Disponível em: www ufff br/admenf/files//Supervisão-em-Enfermagemll pdf.

53. Pilang C, Gray M, Oprescu F. The evolution of the Community Health Worker program in Papua New Guinea. Rural Remote Health.2017; 17(4).1-8.

54. Trapé CA, Soares CB, Dalmaso ASW. Trabalho do Agente Comunitário de Saúde: a dimensão educativa da supervisão. Sociedade em Debate;17(1):11938. 2012.

55. Saúde M. Secretaria de Atenção a Saúde. Departamento de Atenção Básica. Caderno de atenção domiciliar. Brasília: Ministério da Saúde, 2013.

56. Campos MLA, Gomes HE. Organização de domínio de conhecimento e os princípios ranganathianos. Perspectivas em Ciência da Informação. 2003; 8(2) 
57. Savassi LCM, Lage JL, Coelho FLG. Sistematização de instrumento de estratificação de risco familiar: a Escala de Risco Familiar de Coelho-Savassi. JMPHC| J Management Primary Health Care. 2012; 3(2):179-85.

58. Nascimento EPL, Correa CRS. O agente comunitário de saúde: formação, inserção e práticas. Cad Saúde Pública. 2008; 24:1304-13.

59. Santos GAC, et al. Dengue: Prevenção, Controle e Cuidados de Enfermagem-Revisão Integrativa da Literatura 2008-2013. Rev Brasileira Ciências da Saúde. 2016; 20(1):71-8.

60. Cassiolato M, Gueresi S. Como elaborar modelo lógico: roteiro para formular programas e organizar avaliação. Nota Técnica Instituto de Pesquisa Economica Aplicada - IPEA. Brasília set 2010. [Internet]. [citado 21 mai 2019]. Disponível em: http://repositorio.ipea.gov.br/bitstream/11058/5810/1/NT_n06_Como-elaborarmodelo-logico_Disoc_2010-set.pdf.

61. Schwartz E. A singularidade do viver das famílias rurais do extremo sul do Brasil. In: Elsen I, Marcon SS, Silva MRS O viver em família e sua interface com a saúde e a doença Maringá: Eduem:79-93. 2002.

62. Bousso RS, Angelo M. A enfermagem e o cuidado na saúde da família. In: Manual de Enfermagem. São Paulo: Instituto para o Desenvolvimento da Saúde-IDS; 2001.

63. Abrahão AL, Lagrange V. A visita domiciliar como uma estratégia da assistência no domicílio. Modelos de atenção e a saúde da família Rio de Janeiro: EPSJV/Fiocruz; p.151-71. 2007.

64. Costa SM, et al. Agente Comunitário de Saúde: elemento nuclear das ações em saúde. Ciência \& Saúde Coletiva.;18(7):2147-56. [Internet], 2013. [citado 15 ago 2019]. Disponível em: http://www.scielo.br/scielo.php?pid=S1413$81232013000700030 \&$ script=sci_arttext\&tlng=pt.

65. Chaves LDP, Mininel VA, Silva JAM, Alves LR, Silva MF, Camelo SHH. Supervisão de enfermagem para a integralidade do cuidado. Revista Brasileira de Enfermagem, 70(5). [Internet], 2017. [citado 21 mai 2019]. Disponível em: https://www.redalyc.org/pdf/2670/267052669030.pdf. 
66. Muniz JN, Palha PF, Monroe AA, Gonzales RC, Ruffino AR, Villa TCS. A incorporação da busca ativa de sintomáticos respiratórios para o controle da tuberculose na prática do agente comunitário de saúde. Ciência \& Saúde Coletiva;10:315-21, [Internet], 2005. [citado 11 mai 2019]. Disponível em: scielosp.org/scielo.php?pid=\$1413-81232005000200009\&script=sci_abstract.

67.Rosa T. Conselho Nacional de Secretários da Saúde - CONASS. [homepage]. E-SUS Atenção Básica é lançado pelo Ministério da Saúde. [citado 21 mai 2019]. Disponível em: https://www.conass.org.br/consensus/esus-atencao-basica-e-lancado-pelo-ministerio-da-saude/.

68. Nascimento VF, et al. Dificuldades apontadas pelo agente comunitário de saúde na realização do seu trabalho. Saúde - Santa Maria.;43(1):60-9, [Internet], 2017. [citado 11 ago 2019]. Disponível em: https://periodicos.ufsm.br/revistasaude/article/view/23119.

69. Brand $\mathrm{Cl}$, Antunes RM, Fontana RT. Satisfações e insatisfações no trabalho do agente comunitário de saúde.

Cogitare enfermagem;15(1):40-7, [Internet], 2010. [citado 15 ago 2019]. Disponível em: https://www.redalyc.org/pdf/4836/483648970010.pdf.

70. Almeida Jd, Peres MF, Lima TF. O território e as implicações da violência urbana no processo de trabalho dos agentes comunitários de saúde em uma unidade básica. Saúde e Sociedade; 28:207-21, [Internet], 2019. [citado 15 ago 2019]. Disponível em: https://www.scielosp.org/article/sausoc/2019.v28n1/207221/en/.

71. Ferreira $A B H$. Dicionário da língua portuguesa. 5. ed. Curitiba: Positivo; 2010. 
APÊNDICE A - Termo de Consentimento Livre e Esclarecido

NOME:

\section{TERMO DE CONSENTIMENTO LIVRE E ESCLARECIDO DADOS DE IDENTIFICAÇÃO DO SUJEITO DA PESQUISA}

DOCUMENTO DE IDENTIDADE №:

DATA DE NASCIMENTO: / /

ENDEREÇO:

COMPLEMENTO:

CIDADE:

Tendo como propósito a qualificação do trabalho do Agente Comunitário de Saúde na Estratégia Saúde da Família, e compreendendo a supervisão do enfermeiro como estratégica para o alcance dessa finalidade, propõe-se um estudo metodológico voltado à elaboração e validação de um instrumento para planejamento, orientação e acompanhamento pelo Enfermeiro, do trabalho a ser realizado pelo Agente Comunitário de Saúde baseado em uma prática administrativa aberta, flexível, participativa e inovadora. Através do presente estudo denominado "Elaboração e validação de um Instrumento norteador para a supervisão do agente comunitário de saúde pelo enfermeiro: uma ação participativa e colaborativa" objetiva-se elaborar e validar conteúdo instrumento norteador para a supervisão por enfermeiro, do trabalho a ser realizado pelo Agente Comunitário de Saúde na lógica participativa e colaborativa. Convidamos o (a) sr (a) a participar desse estudo por compor a seguinte população alvo: a) Serem enfermeiros; b) Com atuação na Estratégia Saúde da Família por um período igual ou superior há 2 anos; c) Atuantes no município de Sorocaba.

O estudo será desenvolvido por meio da aplicação da técnica Delphi, ocorrerá em três etapas e compreenderá ao preenchimento de um questionário de opinião em cada uma delas.

Na primeira etapa do estudo Delphi, solicita-se que o (a) sr (a) responda a um questionário de opinião com característica exploratória, que objetiva excluir ou modificar itens existentes na versão preliminar do instrumento ou gerar novos itens. O julgamento dos especialistas deverá ser apreendido por meio de escala de opinião de 5 (cinco) pontos, comentários e sugestões. O tempo previsto para preenchimento do questionário é de cerca de 1 hora. Essas ações resultarão na $1^{\underline{a}}$ versão ajustada do instrumento.

$\mathrm{Na} 2^{\text {a }}$ etapa do estudo Delphi, buscar-se-á obter o julgamento dos especialistas em relação ao instrumento quanto ao conteúdo e enunciado de cada um dos itens. Prevê-se a duração aproximada de 45 minutos para preenchimento desse questionário. Com base no nível de consenso de $80 \%$, estabelecido no presente estudo, os itens do instrumento que forem aprovados por $80 \%$ ou mais especialistas em seu conteúdo e linguagem, serão mantidos; itens reprovados em seu conteúdo por mais de 
$20 \%$ dos juízes serão excluídos e itens reprovados por mais de $20 \%$ quanto à linguagem serão modificados, e reapresentados aos juízes na $3^{\underline{a}}$ e ultima etapa do estudo Delphi. Nessa etapa somente os itens modificados serão julgados quanto ao conteúdo e enunciado, gerando a versão consensuada do instrumento.

Sua participação no estudo é voluntária, não implicando em recebimento de pagamento, ou despesa de qualquer espécie. Solicitamos o preenchimento dos questionários e seu re-envio nas distintas etapas num prazo de vinte dias, por correio eletrônico.

Caso consinta em participar do estudo, já por ocasião da primeira etapa, solicitamos que envie juntamente com o questionário preenchido, uma via eletrônica desse termo assinada. Há um risco mínimo na participação desta pesquisa, pois ela pode causar algum constrangimento e desconforto no preenchimento dos questionários, que poderão ser sanados através de orientação do pesquisador responsável. Previmos que o estudo gere benefícios diretos aos participantes na medida em que resultará em instrumento norteador para uso por enfermeiro em seu trabalho com agentes comunitários de saúde. Compartilharemos os resultados da pesquisa, através do envio de cópias do relatório final, em formato eletrônico. Salientamos ainda que o (a) sr (a) terá acesso, a qualquer tempo, às informações sobre objetivos, procedimentos, resultados parciais, riscos e benefícios relacionados à pesquisa e, inclusive para solucionar eventuais dúvidas.

Se você possuir alguma consideração ou dúvida sobre a ética da pesquisa, entre em contato com o Comitê de Ética em Pesquisa (CEP) Av. Dr. Arnaldo, $251-21^{\circ}$ andar - sala 36. Cerqueira César - São Paulo - SP. CEP: 01246-000. Fone/Fax: 55+11+3893-4401/4407. E-mail: cep.fm@usp.br

Acredito ter sido suficientemente informado a respeito das informações que li ou que me foram lidas, descrevendo o estudo "Elaboração e validação de um Instrumento norteador para a supervisão do agente comunitário de saúde pelo enfermeiro: uma ação participativa e colaborativa".

Afirmo que discuti com a pesquisadora a minha decisão de participar neste estudo, estando esclarecido (a) sobre objetivos, procedimentos, riscos e garantia de confidencialidade.

Está claro que a minha participação é isenta de despesas e que tenho direito ao acesso das informações do estudo. Diante disso, concordo voluntariamente em participar deste estudo, havendo a possibilidade de retirar o meu consentimento a qualquer momento, sem penalidades ou prejuízos.

Assinatura do sujeito da pesquisa

Data / /

(Somente para os responsáveis pelo projeto) 
Declaro que obtive de forma apropriada e voluntária o Consentimento Livre e Esclarecido deste indivíduo ou representante legal para a participação neste estudo.

\author{
Assinatura do responsável pela pesquisa \\ Data / / \\ Pesquisadora responsável: \\ Profa Dra. Maria Helena Morgani de Almeida \\ Curso de Terapia Ocupacional da Faculdade de Medicina da USP \\ Rua Cipotânea, 51. Cidade Universitária. Butantã. São Paulo - SP. CEP. \\ 05083-160.Tel: (11)3091-7457 e-mail: hmorgani@usp.br
}

Assinatura do responsável pela pesquisa

Data / /

Pesquisadora executante:

Grasiele Rodrigues de Goes

Tel: (011) 3091-7891/3091-7857/(15) 997570485

grasi.goes@hotmail.com 

Venho por meio dessa, convidá-lo a compor equipe de especialistas que irá participar do processo de validação de um instrumento norteador para a supervisão do agente comunitário de saúde pelo enfermeiro: uma ação participativa e colaborativa. Sua contribuição é valiosíssima para que o material possa ter maior qualidade ao final de todo o processo.

A sua participação será necessária, a princípio, em três etapas distintas:

1. Apreciação da versão preliminar do instrumento quanto a diversos aspectos que a compõem, momento em que poderá sugerir modificações que considere importantes. Nesta etapa, você irá avaliar o quanto concorda ou não com diversas afirmações que direcionam a sua avaliação para aspectos importantes do Instrumento. Além disso, poderá expressar outras observações que não foram contempladas pelo formulário.

2. Após recebermos o seu formulário preenchido e de toda a equipe de especialistas, iremos elaborar a 1 a versão ajustada do instrumento. Novamente iremos submetê-la à sua apreciação, para que aprove ou não as modificações que serão feitas, em relação ao instrumento quanto ao conteúdo e enunciado dos itens gerando assim a $2^{-a}$ versão ajustada do instrumento.

3. Os itens modificados serão apresentados aos especialistas na $3^{\text {a }}$ e ultima etapa do estudo. Nessa etapa, esses itens modificados serão novamente julgados quanto ao conteúdo e linguagem. Essas ações resultarão na versão consensuada do instrumento.

Assim nessa primeira etapa, você está recebendo uma cópia da versão preliminar do instrumento para ser examinada segundo sua experiência e conhecimentos. Sua apreciação deve ser registrada no formulário de avaliação também anexado a essa correspondência.

No formulário, há um campo específico para comentários ou justificativas da sua resposta para cada uma das declarações. Seus comentários são muito importantes, pois eles compõem e complementam sua resposta. Sua opinião objetiva em relação às questões que compõem a Cartilha será fundamental para que possamos confirmar modificar, introduzir e mesmo excluir aspectos deste material.

Solicitamos que o questionário seja preenchido e devolvido em no máximo duas semanas a partir da data do recebimento.

Colocamo-nos à disposição para quaisquer esclarecimentos que se fizerem necessários durante a sua apreciação do material.

Atenciosamente,

Grasiele Góes

grasi.goes@hotmail.com/Tel.: (15)997570485

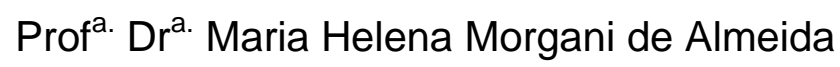
hmorgani@usp.br/ Tel.:(11)30917457 

APÊNDICE C- Questionário de Opinião $1^{1}$ a etapa

Legenda para preenchimento do questionário:

Concordo plenamente: CP

Concordo: C

Nem concordo, nem discordo: NN

Discordo: D

Discordo plenamente: DP

\section{AFIRMAÇÕES}

O instrumento foi construído de modo que o enfermeiro realize uma supervisão que favoreça práticas mais abertas, participativas e colaborativas.

\begin{tabular}{|c|c|c|c|c|}
\hline CP & C & NN & D & DP \\
\hline & & & & \\
\hline
\end{tabular}

Comentários e sugestões:

No que corresponde à disposição dos itens o instrumento está adequado.

\begin{tabular}{|c|c|c|c|c|}
\hline CP & C & NN & D & DP \\
\hline & & & & \\
\hline
\end{tabular}

Comentários e sugestões:

A linguagem adotada no instrumento mostra-se acessível a enfermeiros e ACS.

\begin{tabular}{|c|c|c|c|c|}
\hline CP & C & NN & D & DP \\
\hline & & & & \\
\hline
\end{tabular}

Comentários e sugestões:

O instrumento contém informações que são pertinentes acerca do trabalho desenvolvido pelo ACS.

\begin{tabular}{|c|c|c|c|c|}
\hline CP & C & NN & D & DP \\
\hline & & & & \\
\hline
\end{tabular}

Comentários e sugestões: 
Os dados referentes à produtividade são relevantes para a supervisão do ACS pelo enfermeiro.

\begin{tabular}{|l|l|l|l|l|}
\hline CP & C & NN & D & DP \\
\hline & & & & \\
\hline
\end{tabular}

Comentários e sugestões:

Os dados referentes à vigilância em saúde são relevantes para a supervisão do ACS pelo enfermeiro.

\begin{tabular}{|c|c|c|c|c|}
\hline CP & C & NN & D & DP \\
\hline & & & & \\
\hline
\end{tabular}

Comentários e sugestões:

É pertinente a caracterização de uma família em um instrumento de supervisão.

\begin{tabular}{|c|c|c|c|c|}
\hline CP & C & NN & D & DP \\
\hline & & & & \\
\hline
\end{tabular}

Comentários e sugestões:

No que se refere a caracterização de uma família o propósito do instrumento é contextualizar a estrutura e a dinâmica familiar sua inserção social e questões de saúde.

\begin{tabular}{|c|c|c|c|c|}
\hline CP & C & NN & D & DP \\
\hline & & & & \\
\hline
\end{tabular}

Comentários e sugestões:

A caracterização de uma família visitada deve ser reconstruída periodicamente.

\begin{tabular}{|c|c|c|c|c|}
\hline CP & C & NN & D & DP \\
\hline & & & & \\
\hline
\end{tabular}

Comentários e sugestões: 
A utilização do Genograma e Ecomapa é pertinente para contextualizar a dinâmica familiar e inserção social.

\begin{tabular}{|c|c|c|c|c|}
\hline CP & C & NN & D & DP \\
\hline & & & & \\
\hline
\end{tabular}

Comentários e sugestões:

Os itens dificuldades encontradas pelos ACS em relação ao trabalho no período e problemas identificados pelo enfermeiro e ACS na visita está adequado aos propósitos do instrumento.

\begin{tabular}{|c|c|c|c|c|}
\hline CP & C & NN & D & DP \\
\hline & & & & \\
\hline
\end{tabular}

Comentários e sugestões:

Os itens ações propostas pelo enfermeiro e ACS para a redução dos problemas identificados e acompanhamento e acompanhamento/avaliação das ações propostas está adequado aos propósitos do instrumento.

\begin{tabular}{|c|c|c|c|c|}
\hline CP & C & NN & D & DP \\
\hline & & & & \\
\hline
\end{tabular}

Comentários e sugestões:

O item acompanhamento e avaliação deve ser revisto periodicamente.

\begin{tabular}{|c|c|c|c|c|}
\hline CP & C & NN & D & DP \\
\hline & & & & \\
\hline
\end{tabular}

Comentários e sugestões:

No que se refere à educação em saúde a proposta está adequado aos propósitos do instrumento.

\begin{tabular}{|c|c|c|c|c|}
\hline CP & C & NN & D & DP \\
\hline & & & & \\
\hline
\end{tabular}

Comentários e sugestões: 
Esse instrumento mostra-se como um recurso útil na perspectiva de uma supervisão participativa e colaborativa.

\begin{tabular}{|c|c|c|c|c|}
\hline CP & C & NN & D & DP \\
\hline & & & & \\
\hline
\end{tabular}

Comentários e sugestões:

\section{AGRADECIMENTOS}

Gostaria de prestar meus sinceros agradecimentos por fornecer um pouco do seu tempo e participar dessa $1^{\text {a }}$ etapa da pesquisa. 
APÊNDICE D - Orientações para aplicação do ISACS

O instrumento está estruturado por domínios sendo esses: "Produtividade e Vigilância em Saúde", "Caracterização de uma família visitada", "Dificuldades e problemas Identificados e ações" e "Acompanhamento e Avaliação".

Recomenda-se a utilização do Instrumento pelo Enfermeiro de forma compartilhada com o Agente Comunitário de Saúde (ACS). Enfermeiro e ACS poderão contemplar todas as situações previstas no instrumento numa única supervisão ou realizarem uma supervisão por domínio, a depender da experiência dos participantes.

Ainda que se recomende que um processo de supervisão ocorra de forma contínua, compreende-se que a periodicidade de uso do Instrumento deva ser pactuada de acordo com os problemas levantados e os planos de cuidado estabelecidos.

A supervisão passa assim a ser entendida como um trabalho conjunto que visa facilitar que as próprias equipes analisem suas demandas, suas práticas e reflitam sobre o trabalho e os resultados alcançados, determinando assim um melhor desempenho da equipe e qualidade do serviço prestado. 

Venho através deste convidar para participar da $2^{\mathrm{a}}$ etapa estudo de validação e aproveito a oportunidade para agradecer sua valiosa colaboração na $1^{\underline{a}}$ etapa. Graças a sua apreciação sobre o Instrumento versão preliminar, pude elaborar a 1⿳亠丷厂 versão ajustada do referido instrumento.

Objetivando elaborar uma $2^{\mathbf{a}}$ versão ajustada do instrumento que expresse um grau ainda maior de concordância entre especialistas, solicito que julgue a nossa $1^{\text {a }}$ versão ajustada da seguinte forma:

- Quanto ao conteúdo e linguagem de cada um dos itens do Instrumento. Com base no nível de consenso de $80 \%$, estabelecido no presente estudo, os itens do instrumento que forem aprovados por $80 \%$ ou mais especialistas em seu conteúdo e linguagem, serão mantidos; itens reprovados em seu conteúdo por mais de $20 \%$ dos especialistas serão excluídos e itens reprovados por mais de $20 \%$ quanto à linguagem serão modificados, e reapresentados aos especialistas na $3^{\mathrm{a}}$ e ultima etapa do estudo. Na ultima etapa somente os itens modificados serão julgados quanto ao conteúdo e linguagem, gerando a versão consensuada do instrumento.

- Orientações gerais para aplicação do instrumento.

Assim nessa segunda etapa, você está recebendo uma cópia da $1^{\text {a }}$ versão ajustada do instrumento. Sua apreciação deve ser registrada no formulário de avaliação também anexado a essa correspondência.

No formulário, há um campo específico para comentários ou justificativas da sua resposta para cada uma das declarações. Seus comentários são muito importantes, pois eles compõem e complementam sua resposta.

Solicitamos que o questionário seja preenchido e devolvido em no máximo duas semanas a partir da data do recebimento.

Colocamo-nos à disposição para quaisquer esclarecimentos que se fizerem necessários durante a sua apreciação do material.

Grasiele Góes

grasi.goes@hotmail.com/Tel.: (15)997570485

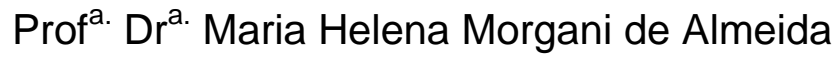
hmorgani@usp.br/ Tel.:(11)30917457 

APÊNDICE F- Questionário de Opinião $2^{\underline{a}}$ etapa

\section{AFIRMAÇÕES}

\section{Produtividade}

Quanto ao conteúdo:

\begin{tabular}{|c|c|}
\hline Aprova ( ) & Não Aprova ( ) \\
\hline Comente sua opinião: & \\
\hline & \\
\hline
\end{tabular}

Quanto à linguagem:

\begin{tabular}{|c|c|}
\hline Aprova ( ) & Não Aprova ( ) \\
\hline Comente sua opinião: & \\
\hline & \\
\hline
\end{tabular}

\section{Vigilância em Saúde}

Quanto ao conteúdo:

\begin{tabular}{|c|c|}
\hline Aprova ( ) & Não Aprova ( ) \\
\hline Comente sua opinião: & \\
\hline & \\
\hline
\end{tabular}

Quanto à linguagem:

\begin{tabular}{|l|l|}
\hline \multicolumn{1}{|c|}{ Aprova ( ) } & Não Aprova ( ) \\
\hline Comente sua opinião: & \\
\hline & \\
\hline
\end{tabular}

Caracterização de uma família visitada: ações a serem desenvolvidas Quanto ao conteúdo:

\begin{tabular}{|c|c|}
\hline Aprova ( ) & Não Aprova ( ) \\
\hline Comente sua opinião: & \\
\hline & \\
\hline
\end{tabular}


Quanto à linguagem:

\begin{tabular}{|c|c|}
\hline Aprova ( ) & Não Aprova ( ) \\
\hline Comente sua opinião: & \\
\hline & \\
\hline
\end{tabular}

Dificuldades e problemas identificados pelo ACS na visita domiciliar e no território

Quanto ao conteúdo:

\begin{tabular}{|c|c|}
\hline Aprova ( ) & Não Aprova ( ) \\
\hline Comente sua opinião: & \\
\hline & \\
\hline
\end{tabular}

Quanto à linguagem:

\begin{tabular}{|c|c|}
\hline Aprova ( ) & Não Aprova ( ) \\
\hline Comente sua opinião: & \\
\hline & \\
\hline
\end{tabular}

Acões desenvolvidas pelo ACS na comunidade, na família ou com o indivíduo.

Quanto ao conteúdo:

\begin{tabular}{|c|c|}
\hline Aprova ( ) & Não Aprova ( ) \\
\hline Comente sua opinião: & \\
\hline & \\
\hline
\end{tabular}

Quanto à linguagem:

\begin{tabular}{|c|c|}
\hline Aprova ( ) & Não Aprova ( ) \\
\hline Comente sua opinião: & \\
\hline & \\
\hline
\end{tabular}

\section{Problemas identificados pela enfermeira na supervisão.}

Quanto ao conteúdo:

\begin{tabular}{|c|c|}
\hline Aprova ( ) & Não Aprova ( ) \\
\hline Comente sua opinião: & \\
\hline
\end{tabular}


Quanto à linguagem:

\begin{tabular}{|c|c|}
\hline Aprova ( ) & Não Aprova ( ) \\
\hline Comente sua opinião: & \\
\hline & \\
\hline
\end{tabular}

Ações propostas pelo enfermeiro e ACS para a redução dos problemas identificados.

Quanto ao conteúdo:

\begin{tabular}{|l|l|}
\hline \multicolumn{1}{|c|}{ Aprova ( ) } & Não Aprova ( ) \\
\hline Comente sua opinião: & \\
\hline & \\
\hline
\end{tabular}

Quanto à linguagem:

\begin{tabular}{|l|l|}
\hline \multicolumn{1}{|c|}{ Aprova ( ) } & Não Aprova ( ) \\
\hline Comente sua opinião: & \\
\hline & \\
\hline
\end{tabular}

Acompanhamento e avaliação das acões

Quanto ao conteúdo:

\begin{tabular}{|c|c|}
\hline Aprova ( ) & Não Aprova ( ) \\
\hline Comente sua opinião: & \\
\hline & \\
\hline
\end{tabular}

Quanto à linguagem:

\begin{tabular}{|l|l|}
\hline \multicolumn{1}{|c|}{ Aprova ( ) } & Não Aprova ( ) \\
\hline Comente sua opinião: & \\
\hline & \\
\hline
\end{tabular}

Proposta de educação em saúde.

Quanto ao conteúdo:

\begin{tabular}{|c|c|}
\hline Aprova ( ) & Não Aprova ( ) \\
\hline Comente sua opinião: & \\
\hline & \\
\hline
\end{tabular}


Quanto à linguagem:

\begin{tabular}{|c|c|}
\hline Aprova ( ) & Não Aprova ( ) \\
\hline Comente sua opinião: & \\
\hline & \\
\hline
\end{tabular}

Orientações gerais para aplicacão do instrumento.

Quanto ao conteúdo:

\begin{tabular}{|c|c|}
\hline Aprova ( ) & Não Aprova ( ) \\
\hline Comente sua opinião: & \\
\hline & \\
\hline
\end{tabular}

Quanto à linguagem:

\begin{tabular}{|c|c|}
\hline Aprova ( ) & Não Aprova ( ) \\
\hline Comente sua opinião: & \\
\hline & \\
\hline
\end{tabular}

\section{AGRADECIMENTOS}

Gostaria de prestar meus sinceros agradecimentos por fornecer um pouco do seu tempo e participar dessa $2^{\mathrm{a}}$ etapa da pesquisa. 
APÊNDICE G- Instrumento: Versão preliminar

\section{Lado A}
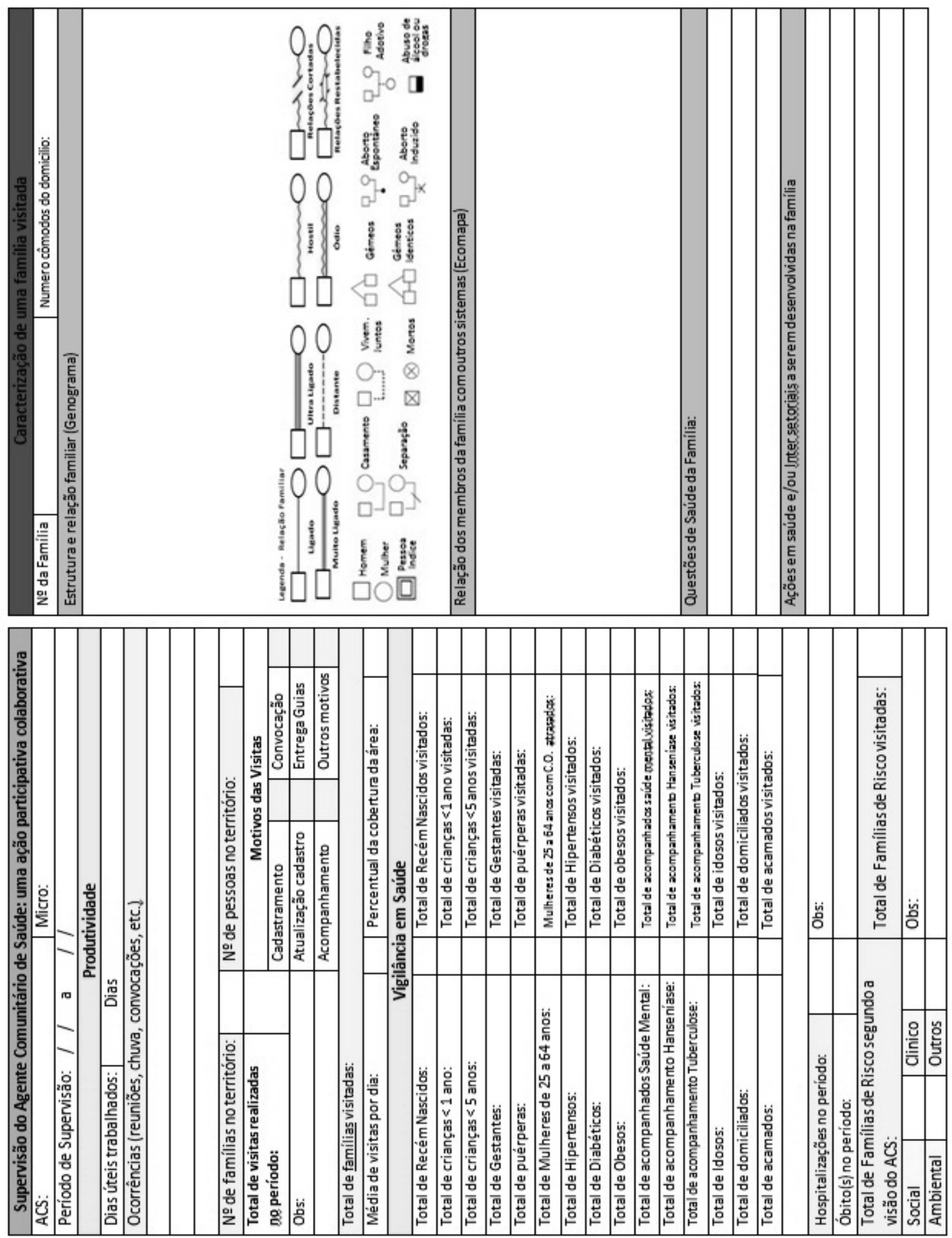
Lado B
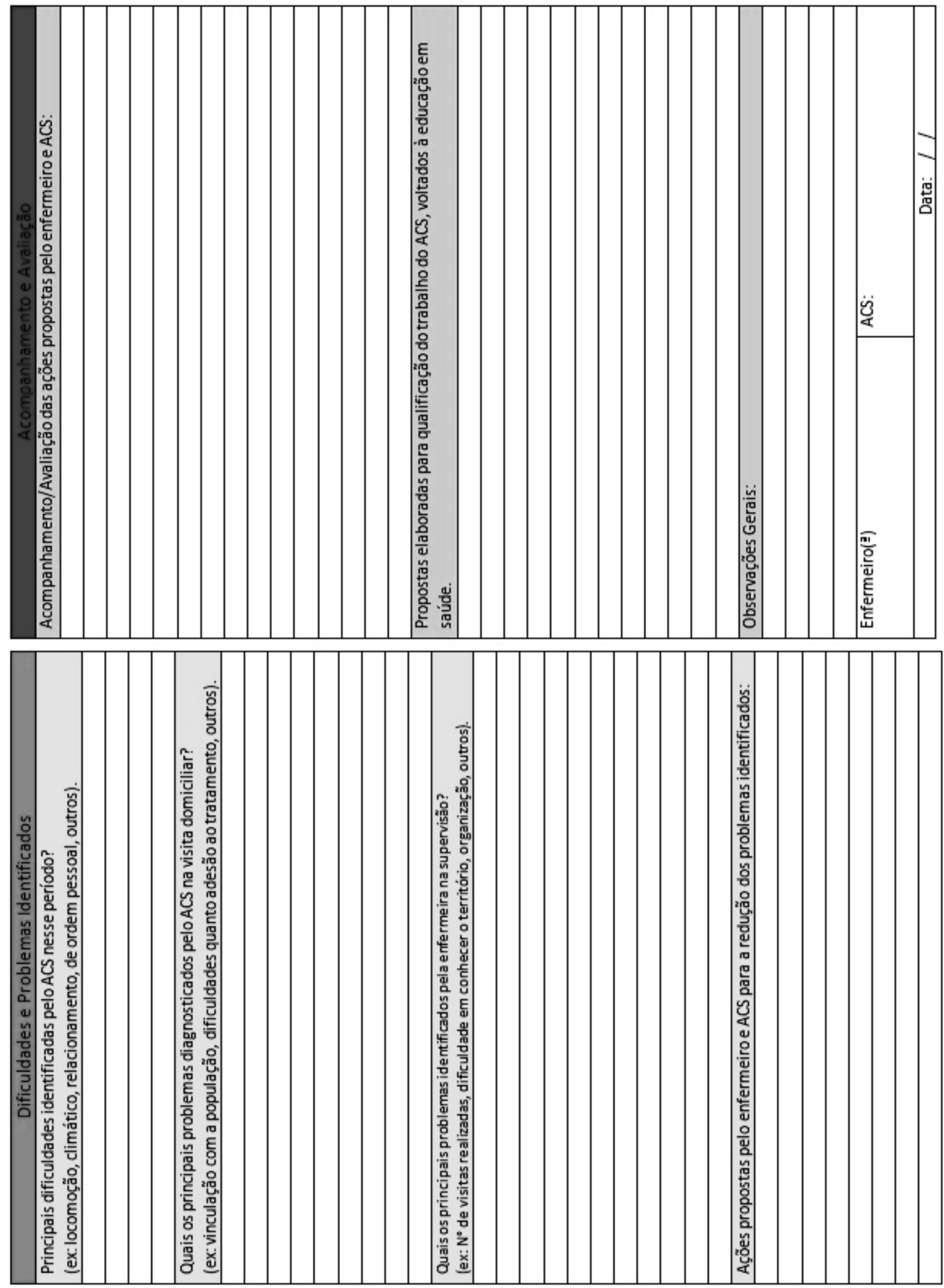
APÊNDICE H - Instrumento: Versão Consensuada

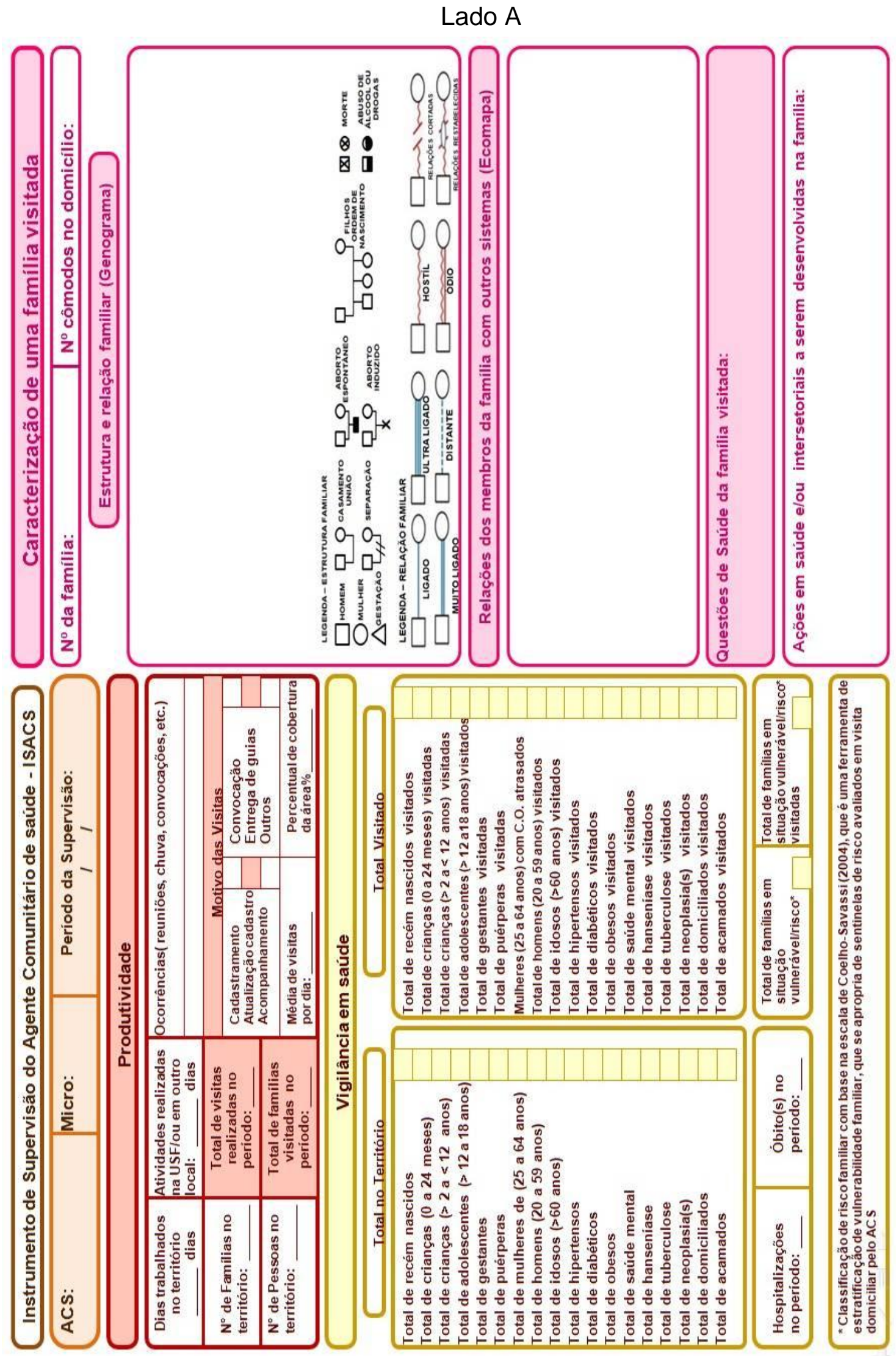


Lado B

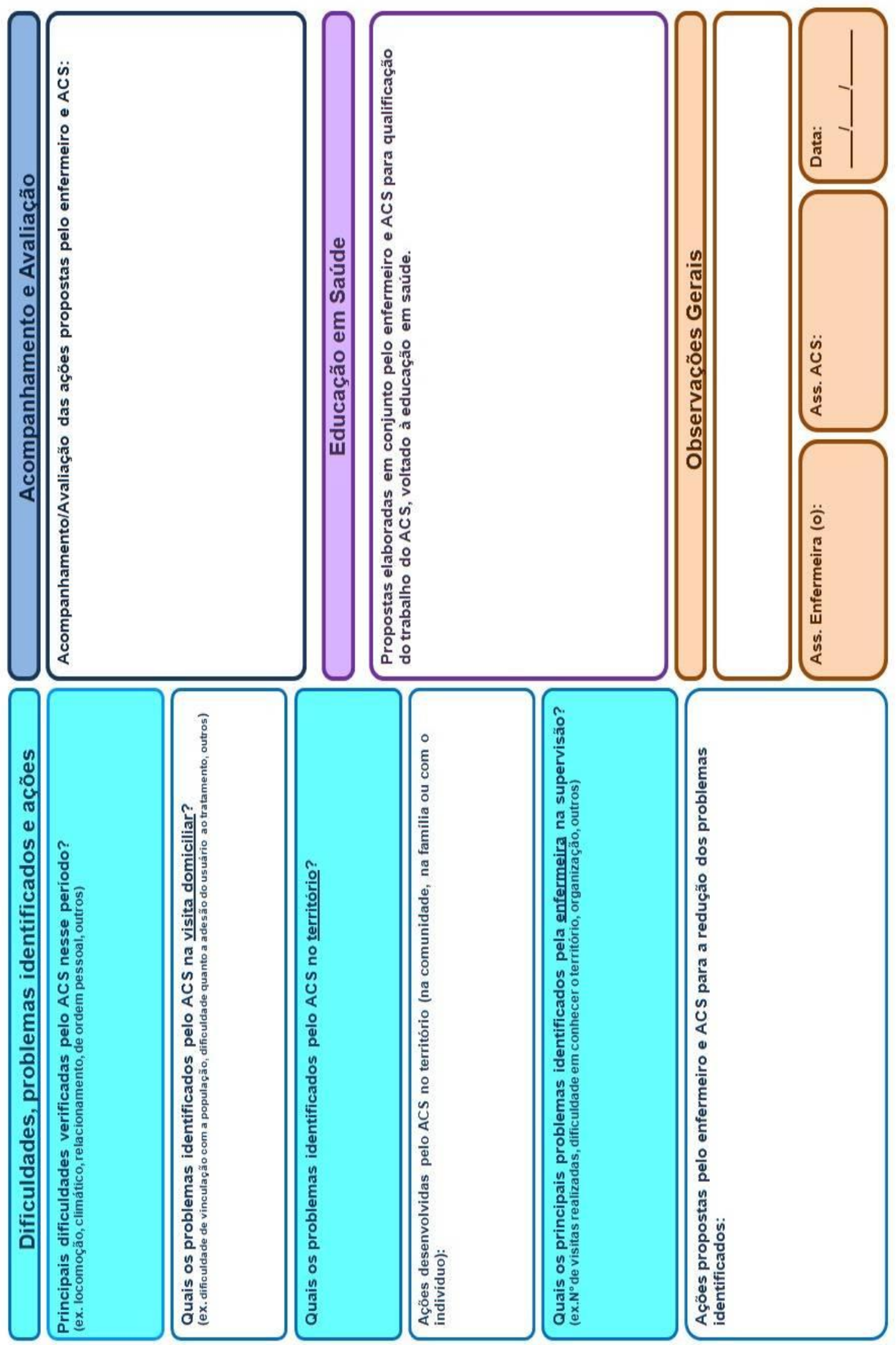


ANEXO A - Parecer do Comitê de Ética em Pesquisa

\section{USP - FACULDADE DE MEDICINA DA UNIVERSIDADE DE SÃO PAULO - FMUSP}

\section{PARECER CONSUBSTANCIADO DO CEP}

\section{DADOS DO PROJETO DE PESQUISA}

Titulo da Pesquisa: Elaboraçăo e validação de um Instrumento norteador para a supervisấo do agente comunitário de saúde pelo enfermeiro: uma açăo participativa e colaborativa

Pesquisador: Maria Helena Morgani de Almeida

Área Temática:

Versāo: 1

CAAE: 84260018.8 .0000 .0065

Instituiçāo Proponente: Faculdade de Medicina da Universidade de Sâo Paulo

Patrocinador Principal: Financiamento Próprio

\section{DADOS DO PARECER}

Número do Parecer: 2.554 .638

\section{Apresentação do Projeto:}

Trata-se de um estudo qualitativo, exploratónio e descritivo em duas fases. A primeira refere-se à elaboração do instrumento, a partir de levantamento bibliográfico e documental. A segunda fase, correspondente a validação de conteúdo do instrumento e será realizada, por meio da aplicaçăo da técnica Delphi.

\section{Objetivo da Pesquisa:}

Objetivo Geral: Elaborar e validar conteúdo de instrumento norteador para a supervisăo do agente comunitário de saúde pelo enfermeiro na lógica participativa e colaborativa.

Objetivos especificos:

- Caracterizar participantes do estudo quanto a características demográficas e profissionais;

- Elaborar proposta de instrumento norteador de supervisăo do trabalho do ACS pelo enfermeiro;

- Validar conteúdo de instrumento norteador de supervisão do trabalho do ACS pelo enfermeiro.

\section{Avaliaçäo dos Riscos e Beneficios:}

Em relaçăo ao beneficios: poderá nortear o enfermeiro em seu trabalho com agentes comunitários de saúde por meio de um instrumento formal.

Riscos: os autores apontam que há um risco minimo na participaçăo desta pesquisa relacionado a

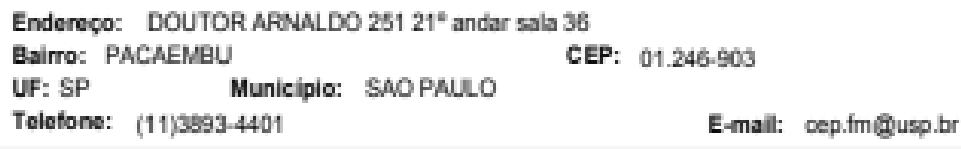




\section{USP - FACULDADE DE MEDICINA DA UNIVERSIDADE DE SÄO PAULO - FMUSP}

Contruactso do Parecer: 2.554 .638

possibilidade de causar algum constrangimento e desconforto no preenchimento dos questionários. Mas sugere a minimizaçăo destes após a orientaçăo do pesquisador responsável.

\section{Comentários e Consideraçōes sobre a Pesquisa:}

O sujeito de pesquisa é o Agente Comunitário de Saúde e o estudo será desenvolvido por meio da aplicaçăo da técnica Delphi (ocorrerá em trés etapas e compreenderá ao preenchimento de um questionário de opiniấo em cada uma delas). Os questionários e seu retorno nas distintas etapas será realizado por correio eletrônico.

\section{Consideraçōes sobre os Termos de apresentaçāo obrigatória:}

O Termo de Consentimento Livre e Esclarecido atende aos requisitos da Lei 466/2012. Ele será enviado e retornado ao pesquisador via correio eletrónico.

Apresentou o Termo de Anuência da Secretaria de Saúde de Sorocaba.

\section{Recomendaçōes:}

Os pesquisadores devem enviar os relatórios semestrais.

Conclusōes ou Pendências e Lista de Inadequaçōes:

Aprovado sem pendências.

Consideraçōes Finais a critério do CEP:

Este parecer foi elaborado baseado nos documentos abaixo relacionados:

\begin{tabular}{|c|c|c|c|c|}
\hline Tipo Documento & Arquivo & Postagem & Autor & Situaçăo \\
\hline $\begin{array}{l}\text { Informaçбes Básicas } \\
\text { do Projeto }\end{array}$ & $\begin{array}{l}\text { PB_INFORMAÇOES_BASICAS_DO_P } \\
\text { ROJETO 1081570.pdf }\end{array}$ & $\begin{array}{c}01 / 03 / 2018 \\
07: 55: 34\end{array}$ & & Aceito \\
\hline Folha de Rosto & Folhaderosto.pdf & $\begin{array}{c}01 / 03 / 2018 \\
07: 52-28\end{array}$ & $\begin{array}{l}\text { Maria Helena } \\
\text { Morgani de Almeida }\end{array}$ & Aceito \\
\hline Outros & CEP.PDF & $\begin{array}{c}01 / 03 / 2018 \\
07: 52: 19\end{array}$ & $\begin{array}{l}\text { Maria Helena } \\
\text { Morgani de Almeida }\end{array}$ & Aceito \\
\hline $\begin{array}{l}\text { Projeto Detalhado / } \\
\text { Brochura } \\
\text { Investigador }\end{array}$ & Projeto.doc & $\begin{array}{c}01 / 03 / 2018 \\
07: 49: 01\end{array}$ & $\begin{array}{l}\text { Maria Helena } \\
\text { Morgani de Almeida }\end{array}$ & Aceito \\
\hline $\begin{array}{l}\text { Declaração de } \\
\text { Instituiçăo e } \\
\text { Infraestrutura }\end{array}$ & anuencia.pdf & $\begin{array}{c}01 / 03 / 2018 \\
07: 48: 44\end{array}$ & $\begin{array}{l}\text { Maria Helena } \\
\text { Morgani de Almeida }\end{array}$ & Aceito \\
\hline $\begin{array}{l}\text { TCLE / Termos de } \\
\text { Assentimento / }\end{array}$ & TCLEdocx & $\begin{array}{c}01 / 03 / 2018 \\
07: 45: 29\end{array}$ & $\begin{array}{l}\text { Maria Helena } \\
\text { Morgani de }\end{array}$ & Aceito \\
\hline
\end{tabular}

Endereço: DOUTOR APWALDO 25121 " andar sala 36

Bairro: PACAEMEU

UF: SP Municipio: SAOPALLO

Telefone: (11)3693-4401

CEP: $01.246-903$

E-mail: cep.fmêusp.br 


\section{USP - FACULDADE DE MEDICINA DA UNIVERSIDADE DE SÄO PAULO - FMUSP}

Cantinuaçso do Parecer: 2.554 .638

Justificativa de TCLEdocx

$01 / 03 / 2018$

Almeida

Platoforma

Ausência $07: 45: 29$

Situaçāo do Parecer:

Aprovado

Necessita Apreciação da CONEP:

Năo

SAO PAULO, 21 de Março de 2018

Assinado por:

Maria Aparecida Azevedo Koike Folgueira

(Coordenador)

Endereço: DOUTOR ARWALDO $25121^{*}$ andar sala 36

Bairro: PACAEMEU

UF: SP

Municipio: SAO PALLO

CEP: $01.246-903$

Telefone: (11)3693-4401

E-mail: cep.fmenusp.br 